\title{
Carotenoids and Chlorophylls as Antioxidants
}

\author{
Antonio Pérez-Gálvez ${ }^{\mathbb{D}}$, Isabel Viera and María Roca *(D)
}

Food Phytochemistry Department, Instituto de la Grasa (CSIC), University Campus, Building 46, 41013 Sevilla, Spain; aperez@ig.csic.es (A.P.-G.); iviera@ig.csic.es (I.V.)

* Correspondence: mroca@ig.csic.es; Tel.: +34-954-611-550

Received: 30 April 2020; Accepted: 6 June 2020; Published: 9 June 2020

check for updates

\begin{abstract}
Chlorophylls and carotenoids are natural pigments that are present in our daily diet, especially with the increasing tendency towards more natural and healthy behaviors among consumers. As disturbed antioxidant homeostasis capacities seem to be implicated in the progress of different pathologies, the antioxidant properties of both groups of lipophilic compounds have been studied. The objective of this review was to analyze the state-of-the-art advances in this field. We conducted a systematic bibliographic search (Web of Science ${ }^{\mathrm{TM}}$ and Scopus $($ ), followed by a comprehensive and critical description of the results, with special emphasis on highly cited and more recently published research. In addition to an evaluative description of the methodologies, this review discussed different approaches used to obtain a physiological perspective, from in vitro studies to in vivo assays using oxidative biomarkers. From a chemical viewpoint, many studies have demonstrated how a pigment's structure influences its antioxidant response and the underlying mechanisms. The major outcome is that this knowledge is essential for interpreting new data in a metabolic networks context in the search for more direct applications to health. A promising era is coming where the term "antioxidant" is understood in terms of its broadest significance.
\end{abstract}

Keywords: ABTS; antioxidant activity; antioxidant capacity; carotenoid; chlorophyll; chlorophyllin; DPPH; LDL; liposomes; Nrf-2

\section{Introduction}

The term "antioxidant" has various different definitions; the concept has been subject to a continuous evolution as research advances [1,2]. For example, the original chemical definition of antioxidant, "any substance that, when present at low concentrations compared to that of an oxidizable substrate, significantly delays or inhibits oxidation of that substrate" [3], has now been overtaken by a biological perspective, i.e., "natural or synthetic substances that may prevent or delay oxidative cell damage caused by physiological oxidants having distinctly positive reduction potentials, covering reactive oxygen species (ROS)/reactive nitrogen species (RNS) and free radicals" [4]. One main reason for this gradual change from chemistry to biology is the progressive and emerging evidence that supports the involvement of oxidative stress in the development of various diseases like diabetes mellitus, cancer, Alzheimer's disease, etc.

The differences in how the terms "activity" and "capacity" are applied in the context of antioxidants should be considered. Antioxidant activity is the constant rate of the reaction between an antioxidant and reactive species (radicals and non-radicals); thus, activity correlates with the interaction of that pair of reactive compounds and the quantitation of the structure-activity relationship. Therefore, antioxidant activity is preferentially measured in model systems (homogeneous solutions), and this approach is useful for establishing mechanism(s) of reaction and ranking the antioxidant activity of a family of compounds. That is, we obtain information concerning the chemistry of the process, but that information is not provided within a biological context. Additional terms can be found in the literature, 
such as "antioxidant power", "antioxidant potential", "antioxidant performance", "antioxidant status", and "antioxidant effect" [1].

Chlorophyll and carotenoid levels and variability in the diet can be increased through the regular ingestion of fruits and vegetables as well as via the intake of seaweeds, microalgae, functional drinks, and food supplements, as a consequence of new and healthy trends in food habits. Carotenoids and, to a lesser extent, chlorophylls have been investigated regarding their abilities to decrease the oxidation of other molecules. The objective of the present review was to critically construct an updated compilation of the main findings regarding the capability of chlorophylls and carotenoids to decrease oxidative stress. This review encompassed research conducted at the in vitro (outside of the normal biological context, commonly called test-tube experiments), ex vivo (assays in cells/tissues/organs developed outside of a biological environment for up to 24 hours and with minimal alterations of natural conditions), and in vivo levels (experiments developed using the whole organism).

\section{Methods Used to Determine the Antioxidant Capacity of Lipophilic Pigments}

Many protocols for determining the antioxidant capacity of chlorophylls and carotenoids have been published; however, we review herein the methods most commonly applied to lipophilic pigments. Initially, the methods were classified by considering whether the protocol focused on primary or secondary antioxidants. The term "primary" refers to chain-breaking antioxidants, assessed through hydrogen atom transfer-based assay (HAT), single-electron-transfer-based assay (SET), ROS-scavenging activities, metal chelation, or preventing lipid peroxidation, whereas the term "secondary" refers to preventive antioxidants acting through a neutralization reaction [1]. We have introduced how the protocols correlate within a biological context, where detoxifying enzymes, gene expression, transcription factors, or biomarkers are essential indicators of the in vivo antioxidant capacity. Clinical/biochemical biomarkers are, when properly determined, the most direct in vivo measurement of antioxidant status and consequently the most straightforward method with which to determine the impact of an ingested target compound in the health status of a subject. Despite the fact that in vivo results are required to make any health claims (see Section 2.4), there is an open debate in the scientific community regarding the relative significance of each methodology. Several reviews support the utility of total antioxidant capacity (TAC) measurements [5], describing the advantages and limitations of these methods. It has been pointed out that the influence of an antioxidant in health could be independent of the direct effect on human cells and tissues [6]. The presence of an antioxidant in food could prevent or inhibit the oxidation of other food components. Ultimately, the selection of the methodology used to determine antioxidant activity/capacity will depend on the objective being pursued, being aware of the major drawbacks of the selected assay to avoid obtaining inaccurate conclusions. Although numerous classifications have been proposed, we followed an integrated approach [1], starting from pioneer works [7-12] and continuing to more recent biochemical assays.

The selection of a suitable protocol depends on factors such as the polarity and structure of the compound, the characteristics of the medium in which the determination is being performed, the feasibility, etc., which are summarized in Table 1. It is important to highlight the case of antioxidant measurements in water/lipid systems that use detergents to produce micellar dispersions of the lipophilic pigments. Some pigments are ineffectively incorporated into micelles under some experimental conditions, and the location of the pigment (in the core or the shield of the aggregates) produces a different result in the radical-scavenging process. Some of the differences attributed to the structural arrangements of pigments and observed in homogeneous systems disappear in heterogeneous systems, whereas other new factors governing the antioxidant process may occur, promoting different and unexpected behavior [11-19].

In addition to the results obtained from this milieu of protocols and applications, other controlling factors have emerged, including the spatial distribution of carotenoids and chlorophylls in molecular aggregates or membranes, the heterogeneous and rigid characteristic of the environment surrounding the molecule, the restriction of molecular mobility in the space, and the co-existence of molecules able 
to interact in the same frame. That is, antioxidant action in heterogeneous environments is a completely different behavioral system, where the concepts and schemes obtained with basic homogenous chemistry are the starting point for ascertaining the actual antioxidant values of lipophilic pigments and any other antioxidant substance.

We have highlighted the influence of the polar paradox in the interpretation of the results when working with chlorophylls and carotenoids as antioxidants. Both families of pigments are, as a general rule, lipophilic pigments, but chlorophylls can also be considered amphipathic molecules. The term "polar paradox" [20,21] refers to polar antioxidants being more active in lipophilic ambient environments than nonpolar antioxidants and, vice versa, nonpolar antioxidants are more effective in oil-in-water emulsions than polar environments. However, recent studies [22] extended the concept with new bases, proposing theories such as the association colloid hypothesis, the cut-off effect, reduced mobility, internalization, or the self-aggregation hypothesis. These new theories have increased the number of factors needed to understand and explain the different behaviors of antioxidant compounds, currently at the in vitro level but with practical applications in the near future.

\subsection{Hydrogen-Atom-Transfer-Based (HAT) Assays}

HAT methods determine the capacity of an antioxidant to quench free radicals by donating a hydrogen atom $(\mathrm{H})$, such as oxygen-radical-absorbance capacity (ORAC) or total radical-trapping antioxidant parameter (TRAP) assays. Although these are considered conventional methods, their applicability is restricted to carotenoids, as this protocol has not yet been applied to chlorophylls. In the ORAC test, peroxyl radicals generated by the thermal decomposition of 2,2'-azobis (2-amidinopropane) dihydrochloride react with a dye and decrease the fluorescence of the target compound, such as fluorescein or a phycoerythrin derivative. The antioxidant capacity of a molecule is measured by its ability to prevent loss of the fluorescence signal by neutralizing peroxyl radicals [7], and this method is especially useful for investigating the efficacy of chain-breaking antioxidants. Antioxidant capacity is generally expressed as Trolox equivalents, abbreviated as Trolox-equivalent antioxidant capacity (TEAC). Opposing results have been reported when comparing ORAC and DPPH methods. For example, a given food might exert a high antioxidant activity with the ORAC test but not with the DPPH assay [8,23], and vice versa.

The TRAP protocol, developed by Wayner [24], has been the most widely used method for measuring the total antioxidant capacity of plasma or serum samples in the last decade. However, its main drawback regarding the oxygen electrode end-point is that the electrode does not maintain its stability over the required time [25]. The TRAP method is characterized by the simultaneous presence of a pro-oxidant molecule, an oxidizable substrate (the target fluorescent protein), and the antioxidant fluid. However, TRAP is not appropriate for the direct measurement of the TAC of lipophilic antioxidants, and is consequently not recommended for nonpolar chlorophylls and carotenoids. However, an alternative (luminol-chemiluminescence-based peroxyl-radical-scavenging capacity (LPSC)) using luminol as the endpoint measurement has been successfully applied for carotenoids [26], comparing antioxidant activity values using different methods. The study noted 10-fold lower antioxidant activity with FRAP, TEAC, and DPPH assays than with the LPSC method.

\subsection{Single-Electron-Transfer-Based Assays}

Single-electron-transfer-based assays (SET assays) are based on the capacity of an antioxidant substance to transfer one electron to reduce metal ions, carbonyls, and radicals [27] through relatively slow reaction kinetics and dependent on $\mathrm{pH}$ and solvents [4]. These methods are not frequently applied for measuring chlorophyll and carotenoid antioxidant activity, although some determinations have been developed through the FRAP or cupric-reducing antioxidant capacity (CUPRAC) protocols.

The FRAP methodology considers the ability to reduce the yellow ferric tripyridyltriazine complex (Fe(III)-TPTZ) to a blue ferrous complex (Fe(II)-TPTZ) by the action of electron-donating antioxidants [28]. The resulting blue color, measured spectrophotometrically at $593 \mathrm{~nm}$, is considered 
to be linearly related to the total reducing capacity of electron-donating antioxidants [29]. The FRAP assay is the only protocol that directly measures antioxidants (or reductants) in a sample, compared to other assays measuring the inhibition of free radicals [30]. However, one of the inconveniences of the FRAP assay is the need for acidic conditions (nonphysiologically low $\mathrm{pH}$ value $=3.6$ ) to maintain iron solubility. The consistency between the FRAP and the ORAC assay was assessed by determining the antioxidant status of watercress, wild rocket, and spinach [31], and the study showed that both methods provided comparable results.

Table 1. Chemical methods applied to measure the antioxidant activity of chlorophylls and carotenoids.

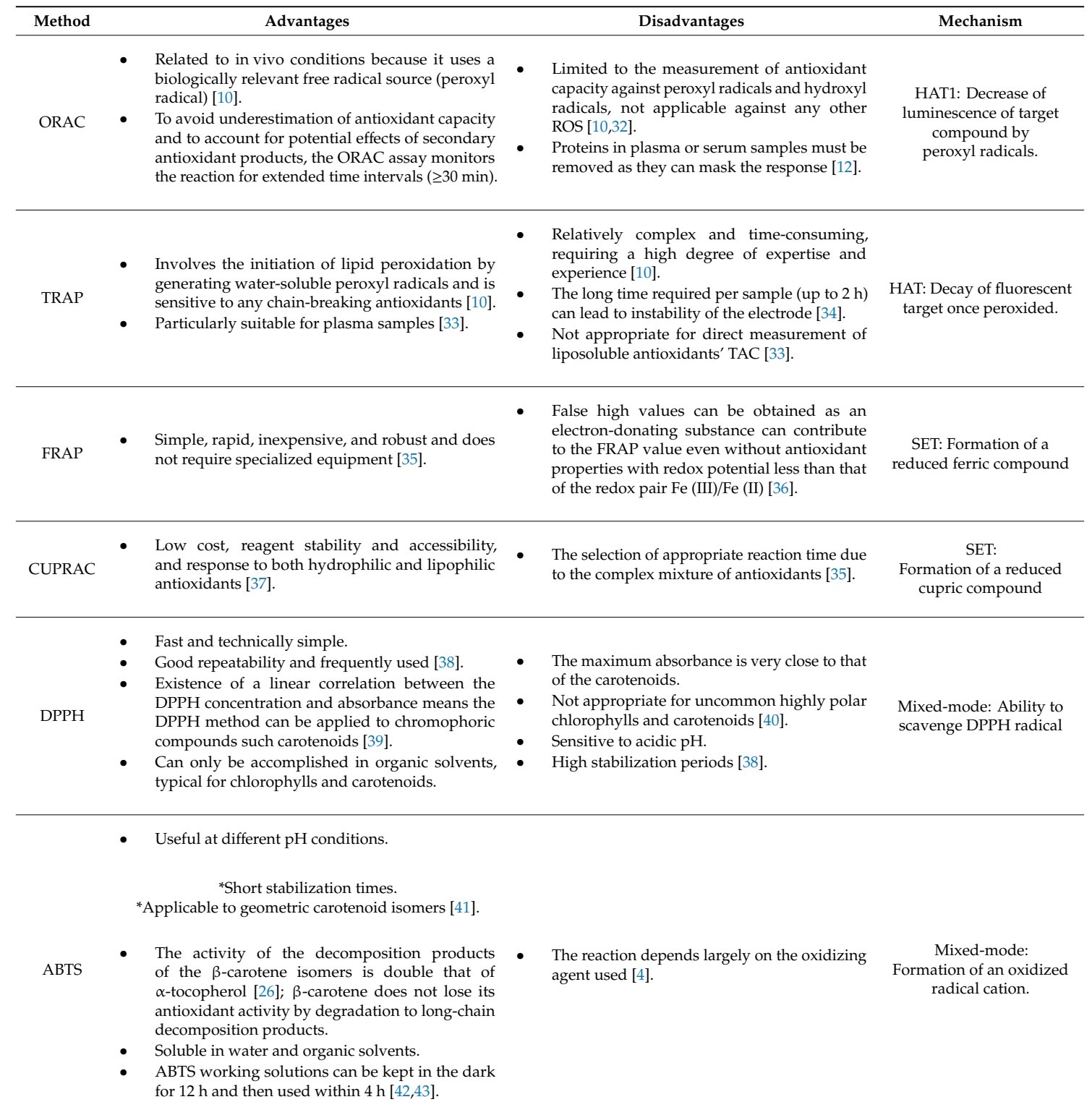

Abbreviations: ORAC: oxygen-radical-absorbance capacity; ROS: reactive oxygen species; TRAP: total radical-trapping antioxidant parameter; TAC: total antioxidant capacity; FRAP: ferric-reducing/antioxidant power; CUPRAC: cupric-reducing antioxidant capacity; DPPH: 2,2-diphenyl-1-picryl-hydrazyl-hydrate; ABTS: 2,2'-azino-bis(3-ethylbenzothiazoline-6-sulfonic acid); HAT: hydrogen-atom-transfer-based assays; SET: single-electron-transfer-based assays.

The CUPRAC assay involves mixing the antioxidant solution with a copper chloride solution (II), an alcoholic neocuproine solution, and an aqueous buffer of ammonium acetate at $\mathrm{pH} 7$, and the subsequent measurement of the absorbance at $450 \mathrm{~nm}$ after $30 \mathrm{~min}$. The CUPRAC reagent is reasonably selective, stable, easily accessible, and sensitive to thiol-type oxidizers, unlike the FRAP procedure. 
The CUPRAC method provides advantages over the FRAP protocol since the reaction is performed at almost physiological pH, compared to the unrealistically acidic pH of FRAP [32], and copper redox chemistry, compared to ferric ion chemistry, involves faster kinetics. However, this method is not suitable for chlorophyll $b$ determinations, as its maximum wavelength absorbance is very close to $450 \mathrm{~nm}$.

\subsection{Mixed-Mode Assays}

In these methods, different mechanisms (HAT, electron transfer (ET), and proton-coupled electron transfer) may be involved in the antioxidant scavenging of a stable radical chromophore [1]. DPPH (uses 2,2-diphenyl-1-picrylhydrazyl as the radical) and ABTS (applies 2, 2'-azino-bis(3-ethylbenz-thiazoline-6-sulfonic acid as the radical) are the most widespread methods used to determine the antioxidant activity of lipophilic pigments.

The DPPH assay is one of the most widely used protocols, [44,45] and it is currently the Association of Official Agricultural Chemists' (AOAC) official method (standard 2012.04-2012) for the total antioxidant determination in foods and beverages [46]. The DPPH radical is a long-lived organic nitrogen radical in which purple chromogen is reduced by antioxidant/reducing compounds to the corresponding pale yellow hydrazine. The reducing ability of antioxidants towards DPPH can be evaluated by electron-spin resonance or by monitoring the absorbance decrease at $515-528 \mathrm{~nm}$ until the absorbance becomes stable in organic media. A modification to the original protocol was proposed to minimize the interference with carotenoids, shifting the monitoring wavelength to $585 \mathrm{~nm}$ [39].

ABTS, when oxidized by peroxyl radicals or other oxidants in the presence of $\mathrm{H}_{2} \mathrm{O}_{2}$, generates a metastable radical cation $\mathrm{ABTS}^{\bullet+}$, which is intensely colored and can be monitored spectrophotometrically in the range of $600-750 \mathrm{~nm}$. The evaluation is based on the ability of antioxidant molecules to quench the long-lived ABTS radical cation [47], measuring the decrease in absorbance. Normally, the activity is expressed relative to the Trolox standard [48] as TEAC. The method only detects radical scavengers and is insensitive to other antioxidant effects.

\subsection{Antioxidant Biomarkers Assessed by In Vivo and Ex Vivo Assays}

Widespread chemical antioxidant activity/capacity assays such as ORAC [7], TRAP [49], TEAC [50], LPSC [51], and FRAP [28], are relatively easy to apply and inexpensive, but they are limited by their inability to represent the complexity of biological systems. They measure chemical reactions, and these reactions are not directly correlated to in vivo activity, as they cannot account for the bioavailability, stability, tissue retention, or reactivity of the compounds under physiological conditions. Biological systems are much more complex than simple chemical mixtures, and antioxidant compounds may operate via multiple mechanisms [52]. The different efficacies of compounds in the various assays attest to their functional variation. The best measures are obtained from animal models and human studies; however, these are expensive and time-consuming, and unsuitable for initial antioxidant screening of foods and dietary supplements. Cell-culture models provide an approach that is cost-effective, relatively fast, and addresses some issues regarding uptake, distribution, and metabolism. Wolfe et al. [53] developed a quantifiable cellular antioxidant-activity assay (CAA) based on the peroxyl-radical oxidation (by AAPH or $\mathrm{H}_{2} \mathrm{O}_{2}$ ) of a bioavailable fluorescent probe forming a fluorescent compound (DCF) within the cells. This method has been successfully applied to carotenoid (Section 3.3.3) and chlorophyll (Section 4.3) antioxidant capacity determination.

Alternatively, multiple oxidatively modified biological molecules are applied as biomarkers of oxidative stress, such as reactive oxygen species (ROS) or reactive nitrogen species (RNS). Along this line and as noted below, the determination of lipid peroxidation products is one of the main methods applied in the study of carotenoid oxidation. Biomarkers such as malondialdehyde (MDA) and lipid hydroperoxides $(\mathrm{LOOH})$, as well as antioxidant assays for estimating lipid peroxidation ( $\beta$-carotene bleaching assay or thiobarbituric-acid-reactive substances (TBARS)), have been successfully used (see below). To provide a general perspective, in vivo studies frequently determine not only the oxidative 
status of lipids by measuring oxidized low-density lipoproteins (LDL) particles, lipid hydroperoxides, and F2-isoprostanes, but also damage to DNA/RNA using the comet assay and protein oxidation products, e.g., protein carbonyls. Among the nucleic acid bases, guanine is the most susceptible to oxidation, with 8-hydroxyguanosine (8-OHG) and 8-hydroxy-2-deoxyguanosine (8-OHdG) being the main oxidative biomarkers determined. DNA damage is also frequently monitored using the comet assay, which detects alterations such as single-strand breaks. The formation of protein carbonyls determines the level of protein oxidation, being measured by HPLC, MS, or by immunochemical detection. Carbonyl groups can form via direct oxidation of certain amino acids (Lys, Pro, Arg, Thr, and His) or by scission of the peptide backbone [54]. Some of the oxidative biomarkers are easily monitored through UV-visible spectrophotometry, whereas others require HPLC methods for quantification.

The importance of these biochemical/clinical markers is supported by the requirements of governmental and control organizations before their approval of a health claim. For example, the FDA (Food and Drug Administration) regulates specific requirements for nutritional content claims using the term "antioxidant" [55], while the EFSA (European Food Safety Agency) has published guidance for the scientific requirements for health claims related to antioxidants and oxidative damage [56]. In general, the EFSA does not consider in vitro or even human plasma antioxidant determinations to be sufficient, as these do not establish a beneficial physiological effect in humans. On the contrary, EFSA establishes that "it is necessary at least one appropriate marker of oxidative modification on the target molecule assessed in vivo in human studies," as shown in Table 2, as a direct in vivo measurement for approval. The EFSA also allows using alternative methods, but only in conjunction with any of the "direct in vivo measurements" listed.

Table 2. Biomarkers approved by the European Food Safety Authority (EFSA).

\begin{tabular}{|c|c|c|c|}
\hline Biomarker & Direct In Vivo Measurement & Alternatives & Not Allowed \\
\hline Protein & $\begin{array}{l}\text { A method that allows separation and identification } \\
\text { of oxidative changes in amino acids (e.g., protein } \\
\text { tyrosine nitration products by LC-MS) }\end{array}$ & $\begin{array}{l}\text { - Protein carbonyls assessed by } \\
\text { ELISA in blood or target tissue } \\
\text { - Conventional assays (e.g., } \\
\text { colorimetric) in plasma samples }\end{array}$ & \\
\hline Lipid & $\begin{array}{l}\text { - Changes in F2-isoprostanes in } 24 \mathrm{~h} \text { samples } \\
\text { assessed using GC-MS or LC-MS } \\
\text { Oxidized LDL particles in blood assessed using } \\
\text { immunological methods } \\
\text { - Lipid hydroperoxides in blood or tissue assessed } \\
\text { by CL-LC }\end{array}$ & $\begin{array}{l}\text { - Appropriate determination of } \\
\text { MDA concentration in blood or } \\
\text { tissues (e.g., LC) }\end{array}$ & $\begin{array}{ll}\text { - } & \text { In vivo TBARS } \\
\text { - } & \text { In vivo MDA } \\
\text { - } & \text { In vivo } \\
& \text { HDL-associated paroxonases } \\
\text { - } & \text { In vivo conjugated dienes } \\
\text { - } & \text { In vivo breath hydrocarbons } \\
\text { - } & \text { In vivo LDL autoantibodies } \\
\text { - } & \text { Ex vivo LDL resistance } \\
& \text { to oxidation }\end{array}$ \\
\hline DNA & $\begin{array}{l}\text { - Modified comet assay (e.g., endonuclease III } \\
\text { plus FPG) }\end{array}$ & $\begin{array}{l}\text { Appropriate determination of } \\
\text { urinary 8-OHdG (e.g., LC) }\end{array}$ & $\begin{array}{l}\text { - Traditional comet assay } \\
\text { - Ex vivo pro-oxidant comet } \\
\text { assay }\end{array}$ \\
\hline
\end{tabular}

\section{Carotenoids as Antioxidants: From Magic Bullets to Dietary Trends}

\subsection{A Conceivable Basis to Consider Carotenoids as Dietary Antioxidants}

As stated in Section 1, the understanding of carotenoids as antioxidant compounds has changed in recent years from just molecules that interact with radical species to biomarkers associated with decreases in different degenerative diseases, including lung, gastrointestinal tract, pancreas, breast, and prostate cancers; cardiovascular disease; and age-related macular degeneration [57-63]. This change in vision has promoted the study of the molecular mechanisms that allow carotenoids to be involved in such multifactorial processes, with corresponding significant advances in knowledge regarding the appearance of carotenoid metabolites [64-67], the absorption and transport processes responsible for the accumulation of carotenoids in specific organs and tissues $[67,68]$, and the increasing number of 
metabolic pathways in which carotenoids can act, resulting in a substantial benefit for health $[56,69,70]$. However, not all the processes through which carotenoids perform their activities have been clarified or even envisaged, and some are not specifically correlated with antioxidant action (retinoid-dependent signaling, enhancement of gap-junction communication, induction of detoxifying enzymes). Most of these activities could be performed in a non-antioxidant manner; therefore, the association between the terms "carotenoids" and "antioxidants" does not fully represent the capabilities of this family of natural pigments.

Carotenoids are isoprenoid-based molecules distributed in all photosynthetic organisms, and some non-photosynthetic bacteria and fungi. In these organisms, the initial steps of the biosynthetic pathway aim to yield the 40 carbon phytoene intermediate. Once this common precursor is produced, a considerable number of chemical and enzymatic processes (desaturation, cyclization, hydroxylation, epoxidation, cleavage of the polyene chain, etc.) may occur several times and, alternatively combined, can yield a wide range of structural arrangements of carotenoid products [71]. Hence, around 1100 carotenoids have been identified in nature, and they are classified into two groups: carotenes (pure hydrocarbons) and xanthophylls (oxygenated products of carotenes). Figure 1 depicts the structures of representative carotenoids, emphasizing those consumed regularly in the human diet, and denoting the characteristic structural arrangements commonly present in these pigments. Carotenes and xanthophylls can be arranged to form the common C40 structure, although biosynthesis of C30 and C50 carotenoids has been described in bacteria, whereas apo-carotenoids are metabolites resulting from shortening the C40 structure of the parent compound. Carotenoids are characterized by their bright yellow to red colors, although some colorless precursors can contribute to the commonly diverse carotenoid profiles that accumulate in organisms. The attractive colorful natures of these compounds results from an extensive chain of conjugated double bonds (Figure 1), and this structural arrangement is the first interactive center of carotenoids with other molecules in the environment [71]. Animals rely on their diet to incorporate these pigments from natural sources, mainly fruits and vegetables, algae, eggs, and fish [72]. The rich variety of carotenoids is far from accessible to us. Our dietary patterns provide us with regular access to 40 carotenoids [73], although this number could significantly increase via the rising inclusion of microalgae in our diet [74]. However, the carotenoid profile in human tissues is mostly comprised of $\alpha$-carotene, $\beta$-carotene, $\beta$-cryptoxanthin, lycopene, lutein, and zeaxanthin [75]. The analysis of human plasma has shown that it contains these and a few other carotenoids, depending on the dietary habits of the study population, whereas even a small number of the pigments mentioned above can accumulate in other tissues, such as lutein and zeaxanthin in the macula lutea, lycopene in the prostate, or xanthophyll esters in human milk [76-78].

The function of carotenoids in a variety of animal species, including humans, is to act as the major precursors of vitamin A, necessary for vision, growth, cell differentiation, and other physiological processes [79]. Only carotenoids with at least one unsubstituted type $\beta$-ring and polyene chain containing 11 carbon atoms (Figure 1 ) belong to the provitamin A category ( $\beta$-carotene and its isomers, $\alpha$-and $\beta$-cryptoxanthin, $\gamma$-carotene, mutatochrome, $\beta$-zeacarotene, and $\beta$-apo- $\beta^{\prime}$-carotenal are main dietary carotenoid contributors to provitamin A activity). This function of carotenoids is key for people that depend on fruits and vegetables to meet their daily required amounts of vitamin $\mathrm{A}$ both in developed and developing countries [80,81]. The significance of this single function of carotenoids in human nutrition does not overshadow some functions performed by carotenoids in photosynthetic organisms that could also somehow be performed in animals.

Carotenoids are essential in photosynthesis for the light-harvesting process and protection against photo-oxidative damage, so we expect carotenoids to function as antioxidants in any organism independently of whether it is photosynthetic. The electron transfer from the characteristic conjugated polyenic chain of carotenoids to the photosystem reaction centers produces an excited state that is essentially dependent on the structural characteristics of the end-groups (Figure 2A). This function in light-harvesting complexes could be exported to other environments, including both cellular and organelle membranes, adipose tissue, and circulating plasmatic lipoproteins, where carotenoids from 
the diet are accumulated in animals. However, there are two issues. First, the antioxidant function of carotenoids in photosynthetic organisms acquires the status of action or activity in non-photosynthetic species, but carotenoids may behave as pro-oxidants under certain circumstances [82], a feature that has not been described in the natural environment of these pigments so far. In line with this idea, we stress that the natural antioxidant function does not necessarily mean an effective in vivo antioxidant action; unexpected (deleterious) activities could occur.

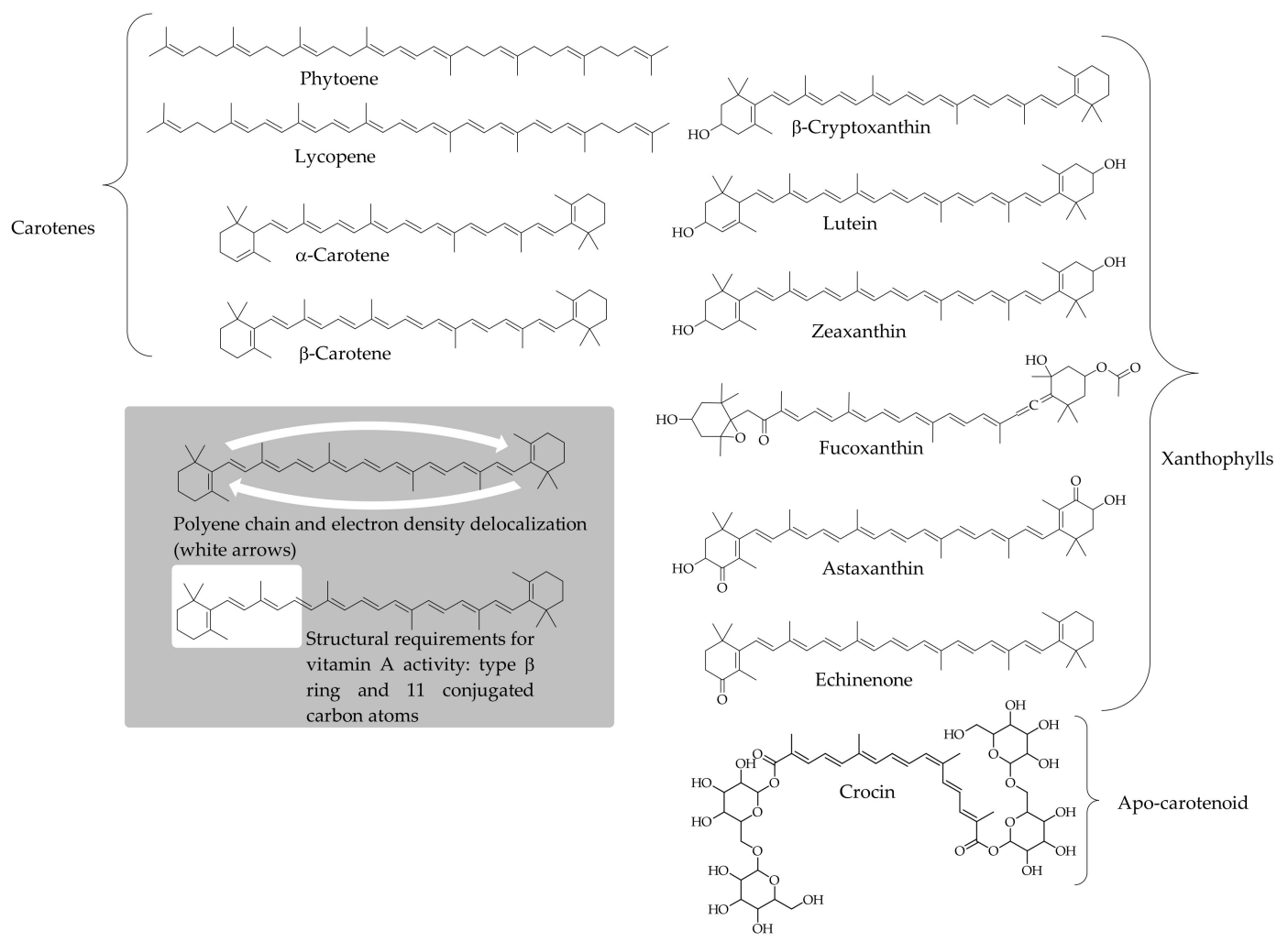

Figure 1. Structure of carotenes and xanthophylls commonly present in dietary sources. The inset represents the conjugated system double-bound through the central carbon atom chain, and the structural requirements that a carotenoid must fulfill to produce vitamin A activity.

The second step was establishing their mode of action, which was promptly formalized [83]. Authors determined carotenoids' high ability to quench singlet oxygen, which is a physical phenomenon through which the excitation energy of singlet oxygen is transferred to the carotenoid molecule and then harmlessly released to the environment, so that the carotenoid finally reaches its original ground state (Figure 2B). This quenching ability is limited and, after several quenching cycles, the carotenoid is oxidized [84]. Carotenoids are nevertheless recognized as potent quenchers of singlet oxygen and the triplet state of porphyrin structures (chlorophylls and protoporphyrin); this was potentially the basis for searching for additional modes of action toward other oxygen free radicals (superoxide anion radical, and hydroxyl and peroxyl radicals), measuring their antioxidant effectivity, and investigating the possible effect of these pigments in the progression of diseases involving radical species [85-88]. The mechanisms and kinetics of these antioxidant process, generally denoted as radical-scavenging chemistry (Figure 2C), have been mainly measured in vitro, ex vivo, and in cell culture models, whereas representative animal studies and clinical trials that appropriately evaluate the in vivo antioxidant effect of carotenoids are limited. 

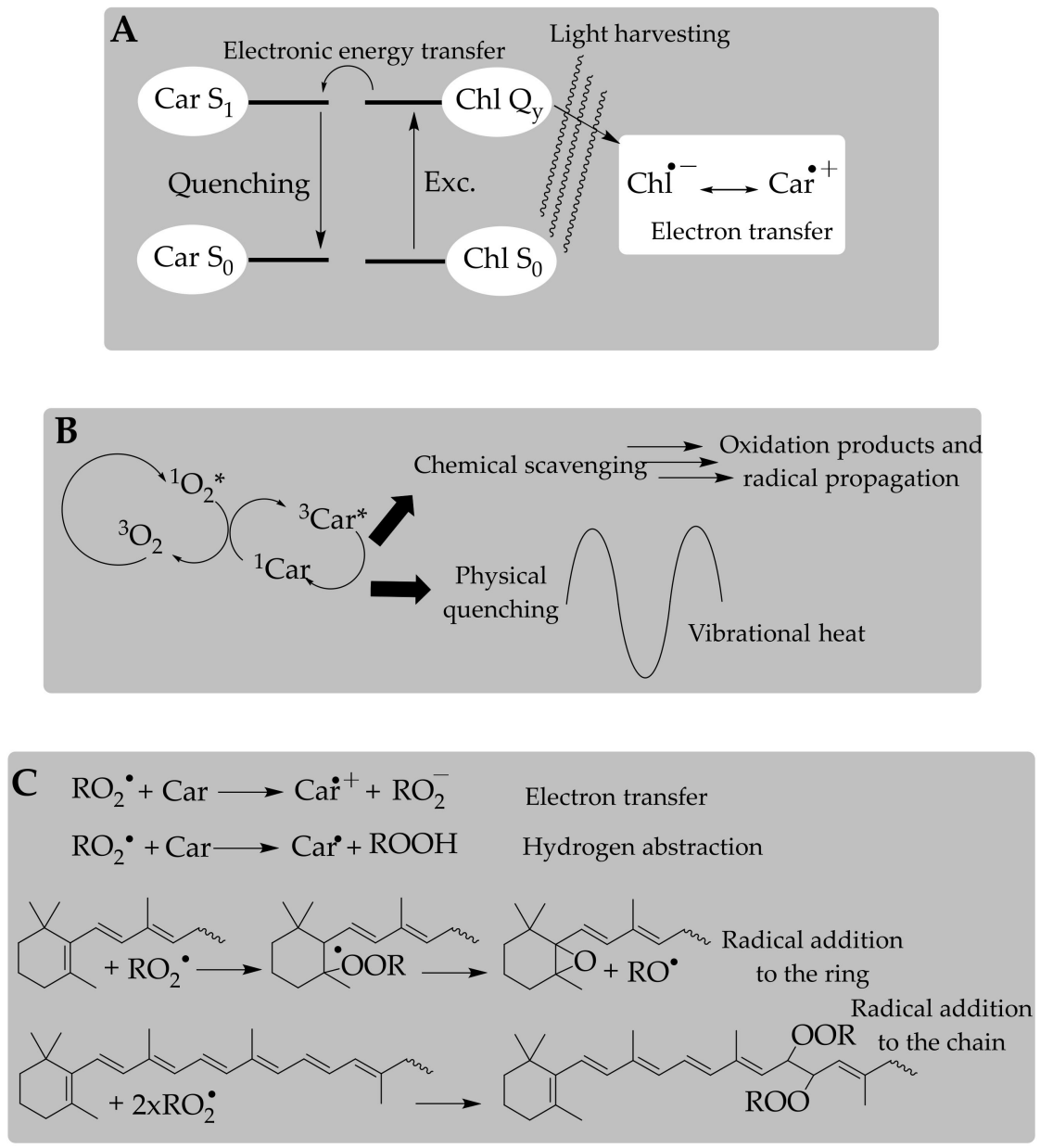

Figure 2. Mechanisms of the antioxidant action exerted by carotenoid pigments in different processes. The electron transfer from the characteristic conjugated polyenic chain of carotenoids to chlorophylls (A). Physical quenching of singlet oxygen (B). Electron transfer, hydrogen abstraction, and radical addition in the antioxidant activity against peroxyl radicals $(\mathbf{C})$.

\subsection{Antioxidant Activity of Carotenoids: In Vitro Approach of a Chemical Process}

Carotenoids are lipophilic antioxidants, with a few exceptions such as crocin and its derivatives which are water-soluble compounds (Figure 1), and they react via different mechanisms, e.g., electron transfer, hydrogen abstraction/reduction, and formation of carotenoid-radical adducts, depending on the redox potential of the radical species and the structural arrangement of the carotenoid.

The electron-transfer mechanism (Figure 2C) involves high-redox-potential radical species [88], and the product of the process is a carotenoid radical cation that decays through dismutation by second-order kinetics [89]. Carotenoid radical cations are long-lived intermediate products and they have a strong oxidizing potential, easily damaging biomolecules (tyrosine, cysteine) [90]. Comparative studies of the antioxidant activities of different carotenoids have reported relative one-electron oxidation potentials that show how xanthophyll radical cations are regenerated to their parent state by carotenes [91]. This repair capacity is also provided by other antioxidants (ascorbic acid, $\alpha$-tocopherol) to carotenoid radical cations [90,92]. The hydrogen abstraction mechanism is a consequence of reduction processes that are correlated with the redox potential of the radical species and with the structural arrangement of the carotenoid. Hence, carotenoids with hydrogen(s) in the allylic position to a double bond react with radical species to yield a resonance-stabilized radical that may continue the radical propagation chain (Figure $2 \mathrm{C}$ ). This reduction process was extensively summarized in the reviews published by Britton [93] and Edge et al. [94]. 
These mechanisms were analyzed using a group of techniques specifically designed to monitor fast reactions (pulse and laser flash photolysis, electron-paramagnetic resonance with spin-trapping capture, and thermal decomposition). The production of carotenoid-radical adducts via radical addition is in some ways the most interesting mechanism, because it involves radical species resulting from the lipid peroxidation process (Figure 2C). In this case, the translation of the antioxidant activity measurement from solutions to molecular aggregates and membranes is logical. The key step is the addition of the radical species to the carotenoid molecule, yielding a radical intermediate through which an unpaired electron is effectively delocalized through the polyene chain [82]. Here is where the structural arrangements of the end-groups play a significant role in the fate of the carotenoid-radical adduct, as the former's characteristics could contribute to enhancing the resonance-stabilized process of the latter species, and consequently its reactivity $[95,96]$. Methodologies based on the reaction chain of the lipid autoxidation process are the basis for establishing protocols to determine antioxidant activity $[97,98]$.

As stated above, the structural arrangements of carotenoids point to the fate of the carotenoid-radical intermediates, but experimental conditions also contribute to the prevalent type of scavenging mechanism involved and the resulting observed effect. Burton and Ingold [82] showed that $\beta$-carotene is an effective antioxidant at low oxygen tensions ( $<150$ Torr), but when higher values are experimentally set up, the behavior switches to a pro-oxidant activity. This indicates that a close interaction exists between the carotenoid structure and oxygen, and that the carotenoid-radical intermediates propagate the effect of the starting radical species under those experimental conditions. However, oxygen tensions in normal physiological conditions are in the range of 145-165 Torr [99] for the lungs and drop to 15 Torr or even less in other tissues [100], so the possible pro-oxidant effect of carotenoids for in vivo systems should be attributed to factors other than oxygen tension.

\subsection{Antioxidant Capacity of Carotenoids: A Further Step to Estimate the In Vivo Antioxidant Action}

Antioxidant capacity is defined as the number of radical species that are removed or neutralized from the environment by an antioxidant substance. That capacity action can be tested in homogeneous environments, as are used to estimate the antioxidant activity. Thus, several protocols can be used to assess how carotenoids scavenge radical species, as reviewed previously, mainly using the oxygen-radical-absorbance capacity (ORAC) [7], total radical-trapping antioxidant parameter (TRAP)-related protocols [24,49,101], ABTS assays [47], and DPPH testing [45]. The chemistry of these methods is expected to predict the antioxidant capacity in in vivo systems with a relatively high-throughput screening ability.

However, some improvements in the design of antioxidant capacity measurements should be introduced if we want to increase the reliability of the data and support the correlation of experimental predictions with in vivo scenarios. The first notion to consider is the fact that carotenoids are transported in lipoproteins and accumulate in the membranes of cells and organelles of tissues. Therefore, experimental procedures with that aim should be combined into one protocol to reproduce the natural surroundings in which carotenoids accumulate, i.e., membranes or molecular aggregates of lipophilic compounds (lipoprotein particles), with one or various protocols used to measure the antioxidant capacity in this mimicked system. Three approaches are commonly applied to build carotenoid-rich domains: preparing artificial membranes or liposomal aqueous suspensions, isolating biological samples (plasma) from a human or animal diet supplemented with antioxidants, or using cell-culture models, which have some other issues in addition to the antioxidant capacity, such as uptake, distribution, and metabolism of the tested antioxidant. Each of these approaches is complemented by a protocol that induces the appearance of one or several radical species, which are scavenged by the membrane antioxidant(s) being tested. 


\subsubsection{Measurement of the Antioxidant Capacity in Liposomes}

The liposome is the simplest approach for studying biological membranes, and is still a significant tool used to manage issues regarding the biochemistry of membrane components. Liposome preparation is easy, taking advantage of the spontaneous aggregation of phospholipids in aqueous environments as closed membrane systems [102]. These membranes are relatively stable, produced with an exactly known and "made-to-order" lipid composition, and may reproduce the fate of membrane lipids in terms of the interfacial phenomena occurring inside and outside of the membrane structure.

Table 3 lists some relevant studies that focused on the antioxidant capacity of carotenoids in liposomes, describing the main features of the experimental protocols and the observed effects. Most of the studies reported a positive correlation between the presence of carotenoids in the membrane system and a lower incidence of the radical-induction process. Additionally, several of the studies included the appearance of synergistic effects in the antioxidant capacity. The method may provide an efficiency ranking of the antioxidant capacity, but significant divergences may arise from the lack of standardization of the protocols (liposomal membrane preparation and radical species strategy). Thus, the following should be considered: diameter and number of lipid bilayers (small unilamellar vesicles, large unilamellar vesicles, and multilamellar vesicles); ratio among lipid contents used to build the artificial membranes; preparation parameters applied; and the presence of membrane antioxidants that may influence membrane properties, such as fluidity, polarity, thermostability, and distribution of lipid categories. All these variables make comparison between studies less than straightforward.

Some of the antioxidant studies of carotenoids performed using the liposome approach revealed properties related to the orientation of these pigments in biological membranes and their ability to suppress radical penetration of oxygen into such membranes. Another interesting lesson learned from this kind of procedure is that the cooperative action between different antioxidant categories produces a synergistic effect on the capacity, a significant result regarding the design of intervention trials and clinical studies.

\subsubsection{Measurement of the Antioxidant Capacity in LDLs}

The ex vivo oxidation of LDL is a method used to evaluate the effect of dietary supplements or food antioxidants on the oxidizability of lipoprotein particles using a fusion of test-tube protocols with in vivo studies, so that the pros and cons of both approaches are joined in a single procedure. The experimental animals or human volunteers participating in such studies follow a specific diet, and the lipoprotein fraction is enriched in these pigments. The first advantage of this method is that the natural particulate matter in which carotenoids are packaged and circulate through the body is accessible. The efficacy of the metabolic processes required to reach the targeted accumulation of carotenoids in lipoproteins is affected by several factors, so the heterogeneity of the biological samples could be high and other antioxidants in addition to carotenoids could be targeted to the lipoprotein fraction.

Another issue to consider is the protocol applied to induce the oxidation of lipids in the isolated lipoprotein fraction and the corresponding selected biomarker for quantification. Here, as detailed in the previous section, there are several options that follow the increase in the molecules that are generated in reaction with radical species, such as the products from lipid peroxidation, including aldehydes (malondialdehyde, 4-hydroxy-2-nonenal), conjugated dienes, and lipid hydroperoxides, or products arising from the oxidation of lipoproteins, including carbonyl groups, and advanced glycation end-products. In addition, antioxidant-capacity protocols such as FRAP or ABTS are directly applied to the isolated lipoprotein fraction. Finally, the antioxidant status of the individual before and after the intervention study can be estimated via the measurement of urine or plasma biomarkers (prostaglandin-like compounds and derivatives, DNA-damage products, reduced/oxidized glutathione (GSH/GSSG) ratio, etc.). 
Table 3. Relevant studies considering the antioxidant capacity of carotenoids in liposomes.

\begin{tabular}{|c|c|c|c|c|}
\hline Experimental Approach $^{1}$ & $\begin{array}{l}\text { Composition of the Membrane } \\
\text { Model; Induction of Oxidative } \\
\text { Stress; Biomarker(s) }\end{array}$ & Carotenoid(s) & Observed Effect & Reference \\
\hline $\begin{array}{l}\text { Lipid peroxidation in } \\
\text { aqueous dispersion of lipids }\end{array}$ & $\begin{array}{l}\text { Dimyristoil phosphatidylcholine } \\
\text { liposomes or soybean } \\
\text { phosphatidylcholine liposomes } \\
\text { enriched with } \beta \text {-carotene; AAPH and } \\
\text { AMVN peroxyl-radical inducers; } \\
\text { phospholipid hydroperoxides, } \\
\text { carotenoid bleaching }\end{array}$ & $\beta$-carotene & $\begin{array}{l}\text { Potential of the antioxidant } \\
\text { capacity of } \beta \text {-carotene is limited } \\
\text { by the carotenoid autoxidation } \\
\text { process that continues the chain } \\
\text { oxidation of membrane lipids }\end{array}$ & [103] \\
\hline $\begin{array}{l}\text { Lipid peroxidation of } \\
\text { liposomal bilayers }\end{array}$ & $\begin{array}{l}\text { Dilinoleoylphosphatidylcholine } \\
\text { liposomes enriched with } \beta \text {-carotene; } \\
\text { AAPH radical inducer; conjugated } \\
\text { dienes, carotenoid bleaching }\end{array}$ & $\beta$-carotene & $\begin{array}{l}\beta \text {-carotene is an effective } \\
\text { chain-breaking antioxidant when } \\
\text { it is incorporated into } \\
\text { the membranes }\end{array}$ & [104] \\
\hline $\begin{array}{l}\text { Lipid peroxidation in } \\
\text { artificial membranes }\end{array}$ & $\begin{array}{l}\text { Egg-yolk phosphatidylcholine } \\
\text { liposomes enriched with a single } \\
\text { carotenoid; AAPH and AMVN } \\
\text { peroxyl-radical inducers; } \\
\text { phospholipid hydroperoxides, } \\
\text { carotenoid bleaching }\end{array}$ & $\begin{array}{l}\text { Astaxanthin, } \\
\beta \text {-carotene, } \\
\text { canthaxanthin, } \\
\text { lycopene, } \\
\text { zeaxanthin; } \\
\text { Antioxidant } \\
\text { activity was } \\
\text { compared with } \\
\alpha \text {-tocopherol }\end{array}$ & $\begin{array}{l}\text { Different reactivity toward free } \\
\text { radicals was correlated with the } \\
\text { structural arrangement of the } \\
\text { carotenoid, its position, and } \\
\text { orientation in the bilayer }\end{array}$ & [105] \\
\hline $\begin{array}{l}\text { Lipid peroxidation in } \\
\text { artificial membranes }\end{array}$ & $\begin{array}{l}\text { Egg-yolk phosphatidylcholine } \\
\text { liposomes enriched with a single } \\
\text { carotenoid; UV radiation and AAPH } \\
\text { peroxyl-radical inducer; TBARS, } \\
\text { carotenoid bleaching }\end{array}$ & Lutein, zeaxanthin & $\begin{array}{l}\text { Both xanthophylls are effective } \\
\text { membrane antioxidants towards } \\
\text { different radical induction } \\
\text { processes; extension of lipid } \\
\text { peroxidation was reduced by } 35 \% \text {; } \\
\text { both xanthophylls promoted } \\
\text { different changes in the } \\
\text { organization of the lipids in } \\
\text { the bilayer }\end{array}$ & [106] \\
\hline $\begin{array}{l}\text { Photoperoxidation of } \\
\text { multilayer liposomes }\end{array}$ & $\begin{array}{l}\text { Egg-yolk phosphatidylcholine } \\
\text { liposomes enriched with individual } \\
\text { carotenoid; hydrogen peroxide, } \\
\text { tert-butyl hydroperoxide, ascorbic } \\
\text { acid, and Fe }{ }^{+2} \text {-EDTA radical inducers; } \\
\text { TBARS, iron concentration } \\
\text { in liposomes }\end{array}$ & $\begin{array}{c}\text { Astaxanthin, } \\
\text { lycopene, peridinin }\end{array}$ & $\begin{array}{l}\text { Structure of the carotenoids } \\
\text { induced changes in the } \\
\text { permeability of the membranes to } \\
\text { radical inducers; a reduction of } \\
25 \% \text { of TBARS was observed after } \\
\text { the addition of carotenoids } \\
\text { to liposomes }\end{array}$ & [107] \\
\hline $\begin{array}{l}\text { Photoperoxidation of } \\
\text { multilayer liposomes }\end{array}$ & $\begin{array}{c}\text { Dimyristoil } \\
\text { phosphatidylcholine/palmitoyl-oleoyl } \\
\text { phosphatidylcholine/cholesterol } \\
\text { liposomes enriched with individual or } \\
\text { combined antioxidants; aerobic } \\
\text { photo-peroxidation; lipid } \\
\text { hydroperoxides, carotenoid bleaching, } \\
\text { oxygen photo-uptake }\end{array}$ & Zeaxanthin & $\begin{array}{l}\text { Zeaxanthin is an efficient } \\
\text { membrane antioxidant toward } \\
\text { singlet oxygen with a synergistic } \\
\text { effect with } \alpha \text {-tocopherol; } \\
\text { Zeaxanthin is } 30 \text { times more } \\
\text { effective than } \alpha \text {-tocopherol in } \\
\text { inhibiting photosensitized } \\
\text { lipid peroxidation }\end{array}$ & [108] \\
\hline $\begin{array}{l}\text { Lipid peroxidation in } \\
\text { unilamellar liposomes }\end{array}$ & $\begin{array}{c}\text { Soybean phosphatidylcholine } \\
\text { liposomes enriched with combined } \\
\text { antioxidants; AAPH peroxyl-radical } \\
\text { inducer; conjugated dienes }\end{array}$ & $\begin{array}{l}\beta \text {-carotene, } \\
\text { lycopene }\end{array}$ & $\begin{array}{l}\text { Synergistic effects of carotenoids } \\
\text { and tocopherols toward the lipid } \\
\text { peroxidation process }\end{array}$ & [109] \\
\hline $\begin{array}{l}\text { Lipid peroxidation in } \\
\text { unilamellar liposomes }\end{array}$ & $\begin{array}{c}\text { Soybean phosphatidylcholine } \\
\text { liposomes enriched with combined } \\
\text { antioxidants; AAPH peroxyl-radical } \\
\text { inducer; conjugated dienes }\end{array}$ & Astaxanthin & $\begin{array}{l}\text { Synergistic effects of astaxanthin } \\
\text { with both hydrophilic and } \\
\text { lipophilic antioxidants were } \\
\text { not significant }\end{array}$ & [110] \\
\hline $\begin{array}{l}\text { Lipid peroxidation in } \\
\text { artificial membranes }\end{array}$ & $\begin{array}{l}\text { Multilamellar liposomes enriched } \\
\text { with PUFA/carotenoid; autoxidation; } \\
\text { hydroperoxides, } \\
\text { membrane interactions }\end{array}$ & $\begin{array}{l}\text { Astaxanthin, } \\
\beta \text {-carotene, lutein, } \\
\text { lycopene, } \\
\text { zeaxanthin }\end{array}$ & $\begin{array}{c}\text { Apolar carotenoids behaved as } \\
\text { membrane pro-oxidants, } \\
\text { increasing the peroxide formation } \\
\text { by } 90-120 \% \text {, whereas astaxanthin } \\
\text { behaved as an antioxidant, } \\
\text { decreasing the peroxide formation } \\
\text { by } 30 \%\end{array}$ & [111] \\
\hline
\end{tabular}

\footnotetext{
${ }^{1}$ Methods and experimental approach were developed by the authors, so the reader is advised to comprehensively review the studies included in this table. Abbreviations: AAPH: 2,2'-Azobis(2-methylpropionamidine) dihydrochloride; AMVN: 2,2'-azobis (2,4-dimethylvaleronitrile; TBARS: thiobarbituric-acid-reactive substances; PUFA: polyunsaturated fatty acids.
}

Table 4 shows some of representative human studies that applied the ex vivo oxidation of LDL method to carotenoids, indicating the characteristics of the intervention group (healthy subjects or population at risk of oxidative-stress-related pathologies), diet, the analyzed biomarkers, and the outlined conclusions. Most of the studies showed that after enrichment of LDL with carotenoid(s), they were less prone to oxidation, whereas no effect or even a deleterious action was the effect 
observed in other studies. To clearly ascertain the quality of such evidence, various critical issues should be considered, such as the design of the intervention trial (randomization, placebo-controlled, blinding), the characteristics of the study population (healthy, smokers, patients), the intervention time and dosage strategy (single-compound or cocktail of antioxidants as supplements, food extracts, or foods), and the number of biomarkers used to control the antioxidant capacity. Hence, those studies where the intervention was aimed to be a preventive therapy provided positive results. In contrast, when therapeutic measurement was the focus, the results tended to be unclear for one or several biomarkers, and the conclusions were inconsistent. Another issue is that in the studies where a mixture of antioxidants was used, including different carotenoids as well as tocopherols, phenols, or ascorbic acid, the tendency was towards a positive relationship between increased levels of antioxidants in LDL and resistance to oxidizability. The same trend was observed for studies with foods instead of supplements, or when the content of antioxidants supplied to the volunteers with the latter products did not reach supraphysiologic levels. Interpreting whether these results should be attributed to an increase in carotenoid levels of LDL or to other components of the diet is difficult.

Table 4. Relevant studies dealing with the ex vivo antioxidant capacity of carotenoids in LDLs.

\begin{tabular}{|c|c|c|c|c|}
\hline Experimental Approach & $\begin{array}{c}\text { Participants; Supplementation Protocol; } \\
\text { Biomarkers of Oxidative Stress; } \\
\text { Relevant Methodologies }\end{array}$ & Carotenoids & Observed Effect & Reference \\
\hline $\begin{array}{l}\text { Supplementation/ex vivo } \\
\text { LDL oxidation }\end{array}$ & $\begin{array}{l}\text { Group of male nonsmokers and smokers; } \\
\text { supplementation with } \beta \text {-carotene }(2 \times 20 \\
\text { mg daily for two weeks, and then } 20 \mathrm{mg} \\
\text { daily for } 12 \text { weeks); lipid peroxidation of } \\
\text { LDL isolates [112] }\end{array}$ & $\beta$-carotene & $\begin{array}{l}\text { No protective effect of LDL } \\
\text { susceptibility to oxidation } \\
\text { despite the observed increase in } \\
\text { plasma } \beta \text {-carotene levels }\end{array}$ & [113] \\
\hline $\begin{array}{l}\text { Supplementation/ex vivo biomarkers } \\
\text { of oxidative stress }\end{array}$ & $\begin{array}{l}\text { Group of } 11 \text { smokers and } 11 \text { nonsmokers; } \\
\text { supplementation with fruits and } \\
\text { vegetables providing } 30 \mathrm{mg} \\
\text { carotenoids/day for } 2 \text { weeks; lipid } \\
\text { peroxidation of LDL isolate } \\
\text { supplementation, oxidative stress } \\
\text { biomarkers of plasma [112] }\end{array}$ & $\begin{array}{c}\alpha \text {-carotene, } \\
\beta \text {-carotene, lutein, } \\
\text { lycopene, } \\
\alpha \text {-cryptoxanthin, } \\
\beta \text {-cryptoxanthin }\end{array}$ & $\begin{array}{l}\text { Inhibition of LDL susceptibility } \\
\text { to oxidation for the smokers and } \\
\text { nonsmokers. LDL resistance to } \\
\text { oxidation increased } 14 \% \text { in } \\
\text { smokers and } 28 \% \text { in the } \\
\text { nonsmokers group after } \\
\text { supplementation }\end{array}$ & [114] \\
\hline $\begin{array}{l}\text { Supplementation/ex vivo biomarkers } \\
\text { of oxidative stress }\end{array}$ & $\begin{array}{c}\text { Group of } 32 \text { healthy volunteers; } \\
\text { double-blind randomized, } \\
\text { placebo-controlled trial, supplementation } \\
\text { with a mixture of carotenoids providing } \\
7.6 \text { mg carotenoids/day for } 3 \text { weeks; lipid } \\
\text { peroxidation of LDL isolates, DNA } \\
\text { damage, ORAC [8,112] }\end{array}$ & $\begin{array}{l}\text { Lycopene, palm oil } \\
\text { carotenes, } \\
\text { marigold extract } \\
\text { carotenoids, } \\
\text { paprika } \\
\text { carotenoids, bixin }\end{array}$ & $\begin{array}{l}\text { The carotenoid supplementation } \\
\text { reduced the LDL oxidizability } \\
\text { (by } 20.4 \% \text { in the supplemented } \\
\text { group) and DNA damage } \\
\text { assessed by urine biomarkers; } \\
\text { the effect was not observed with } \\
\text { the ORAC assay }\end{array}$ & [115] \\
\hline $\begin{array}{l}\text { Supplementation/ex vivo biomarkers } \\
\text { of oxidative stress }\end{array}$ & $\begin{array}{l}\text { Group of } 105 \text { healthy volunteers; } \\
\text { randomized, double-blind, } \\
\text { placebo-controlled; commercial spread } \\
\text { providing with a mixture of carotenoids } \\
\text { at different doses for } 11 \text { weeks; lipid } \\
\text { peroxidation of LDL isolates, plasma } \\
\text { FRAP, MDA, serum arylesterase activity, } \\
\text { plasma } F_{2 \alpha} \text {-isoprostanes; }[28,112]\end{array}$ & $\begin{array}{l}\text { Lycopene, lutein, } \\
\alpha \text {-carotene, } \\
\beta \text {-carotene }\end{array}$ & $\begin{array}{c}\text { Moderate amounts of } \\
\text { carotenoids resulted in a } \\
\text { significantly increased resistance } \\
\text { of LDL to oxidation and lower } \\
\text { plasma peroxidation biomarkers } \\
\text { (17\% increase of LDL resistance } \\
\text { to oxidation, } 18 \% \text { increase of } \\
\text { lag-phase, and } 15 \% \text { reduction in } \\
\text { the F2-isoprostane level) }\end{array}$ & [116] \\
\hline $\begin{array}{l}\text { Supplementation/ex vivo } \\
\text { LDL oxidation }\end{array}$ & $\begin{array}{l}\text { Group of } 12 \text { healthy female volunteers; } \\
\text { supplementation with tomato products } \\
\text { providing } 8 \text { mg lycopene/day for } 21 \text { days; } \\
\text { lipid peroxidation of LDL isolates, } \\
\text { urinary } 8 \text {-iso-PGF } 2 \alpha[112,117]\end{array}$ & Lycopene & $\begin{array}{l}\text { Decrease in LDL oxidizability } \\
(22 \%) \text { and significant lower } \\
\text { excretion of } 8 \text {-iso-PGF } 2 \alpha(53 \%) \\
\text { regarding the values reached in } \\
\text { the control group }\end{array}$ & [118] \\
\hline \multirow[t]{2}{*}{$\begin{array}{c}\text { In vitro loading of LDL/biomarkers of } \\
\text { oxidative stress }\end{array}$} & $\begin{array}{l}\text { Group of } 10 \text { volunteers donated plasma } \\
\text { samples for LDL isolation; in vitro } \\
\text { loading was performed with lycopene or } \\
\text { lutein via emulgent and incubation; lipid } \\
\text { peroxidation and oxidation of ApoB of } \\
\text { LDL isolates [108] }\end{array}$ & Lycopene, lutein & $\begin{array}{l}\text { Carotenoids were not effective } \\
\text { antioxidants of the LDL }\end{array}$ & [119] \\
\hline & $\begin{array}{l}\text { Group of } 35 \text { patients with T2DM; } \\
\text { double-blind, placebo-controlled; } \\
\text { supplementation with lycopene, } 10 \\
\text { mg/day for } 8 \text { weeks; total antioxidant } \\
\text { capacity assessed via ABTS, MDA, } \\
\text { humoral immunity biomarkers }\end{array}$ & Lycopene & $\begin{array}{c}\text { Increased ratio of total } \\
\text { antioxidant capacity to MDA } \\
\text { values and attenuated } \\
\text { pro-atherogenic } \\
\text { immune response }\end{array}$ & [120] \\
\hline $\begin{array}{l}\text { Supplementation/ex vivo } \\
\text { LDL oxidation }\end{array}$ & $\begin{array}{l}\text { Group of } 77 \text { healthy male and female } \\
\text { volunteers; double-blind randomized, } \\
\text { placebo-controlled trial, lycopene } \\
\text { supplement at different doses for } 8 \text { weeks; } \\
\text { lipid peroxidation of LDL isolates, MDA } \\
\text { and HNE, urinary 8-iso-PGF } 2 \alpha, \text { DNA } \\
\text { damage markers }\end{array}$ & Lycopene & $\begin{array}{c}\text { Significant decrease in DNA } \\
\text { damage }(8.9 \%) \text { and urinary } \\
\text { 8-iso-PGF } 2 \alpha \text { levels }(23 \%) \text { in the } \\
\text { supplemented group; no } \\
\text { significant effect was observed } \\
\text { in biomarkers of lipid } \\
\text { peroxidation }\end{array}$ & [121] \\
\hline
\end{tabular}


Table 4. Cont.

\begin{tabular}{cccc}
\hline Experimental Approach & $\begin{array}{c}\text { Participants; Supplementation Protocol; } \\
\text { Biomarkers of Oxidative Stress; } \\
\text { Relevant Methodologies }\end{array}$ & Carotenoids & Observed Effect \\
\hline $\begin{array}{c}\text { Supplementation/ex vivo biomarkers } \\
\text { of oxidative stress }\end{array}$ & $\begin{array}{c}\text { Group of 126 healthy men; randomized } \\
\text { placebo-controlled trial, lycopene } \\
\text { supplementation at different doses for } 8 \\
\text { weeks; SOD activity in plasma, DNA } \\
\text { damage, biomarkers of } \\
\text { endothelial function }\end{array}$ & $\begin{array}{c}\text { Lycopene, } \\
\beta \text {-carotene }\end{array}$ & $\begin{array}{c}\text { Increase in SOD activity (2.37 } \\
\text { units/mL) and prevention of } \\
\text { DNA damage (for the 15 } \\
\text { mg/day suppl. group); }\end{array}$ \\
$\begin{array}{c}\text { beneficial effects in subjects with } \\
\text { relatively impaired endothelial } \\
\text { cell function }\end{array}$ \\
\hline
\end{tabular}

Abbreviations: SOD: superoxide reductase; suppl.: supplemented; T2DM: type 2 diabetes mellitus.

\subsubsection{Measurement of the Antioxidant Capacity in Cell Models: Carotenoid Oxidation Products}

Cell-culture models were the previous proof of concept for in vivo studies, and allowed researchers to ascertain the behavior of antioxidant in more complex situations. As such, the antioxidant effect of carotenoids in cellular models encompasses the protective effect on membrane lipids with the (indirect) reduction in oxidative stress of other significant biomolecules, including DNA [123]; the modulation of cellular responses to inflammation mediated by nuclear receptors [124-126]; the stimulatory effects on a cell-to-cell communication via gap junctions and cell growth [127,128]; and the activity of oxygenases in mitochondrial membranes as a source of carotenoid breakdown products [129-131]. Most studies performed with cell-culture models were established with cell lines representing tissues where carotenoids are transported, accumulated, or metabolized, such as intestinal epithelium, macrophages, adipocytes, human dermal fibroblasts, keratinocytes, and retinal pigment epithelium; erythrocytes, retinal neurons, and other cell lines have also been applied. Table 5 includes representative studies conducted with cell-culture models. Significantly, most of the studies reported positive results, pointing to a synergistic effect with other membrane antioxidants and outlining the contribution of carotenoid breakdown products to possible deleterious effects on the expected antioxidant behavior. Studies in cell cultures provided the basis of our knowledge of the non-antioxidant actions of carotenoids and other membrane antioxidants, as well as pointing to plausible modes of actions in completely different arenas, such as experimental animal models and clinical studies and analyses of epidemiological data [132]. Thus, studying the antioxidant-responsive elements that mediate the transcriptional control of the expression of Phase II enzymes (see below), the identification of carotenoid breakdown products, and the general response to inflammation are research issues currently outstanding, and should be directly evaluated at the in vivo level. To establish the quality of evidence, various critical issues and study limitations should be considered, such as the dosage strategy (physiological or supraphysiological dose, application of the antioxidant supplement to the cell culture in organic solvents, micelles, or lipoproteins), the intervention time, and the number of cellular biomarkers used to control the antioxidant capacity.

Table 5. Relevant studies dealing with the antioxidant capacity of carotenoids in cell systems.

\begin{tabular}{|c|c|c|c|c|}
\hline Experimental Approach & $\begin{array}{c}\text { Cell Model; Induction of } \\
\text { Oxidative Stress; Biomarker(s) }\end{array}$ & Carotenoids & Observed Effect & Reference \\
\hline Cellular membrane oxidation & $\begin{array}{l}\text { Human HepG2 cells; tert-butyl } \\
\text { hydroperoxide; lipid peroxidation } \\
\text { and cellular leakage of } \\
\text { lactate dehydrogenase }\end{array}$ & $\begin{array}{l}\text { Micellar } \beta \text {-carotene } \\
(1.1 \mu \mathrm{mol} / \mathrm{L}) \text { or lutein } \\
(10.9 \mu \mathrm{mol} / \mathrm{L})\end{array}$ & $\begin{array}{l}\text { Protection of cellular membrane } \\
\text { toward oxidant-induced changes }\end{array}$ & [133] \\
\hline Lipid peroxidation & $\begin{array}{l}\text { Normal and tumor thymocytes; } \\
\text { AAPH and xanthine/xanthine } \\
\text { oxidase, at low or high } \mathrm{pO}_{2} ; \mathrm{MDA} \\
\text { and conjugated dienes }\end{array}$ & $\begin{array}{l}\beta \text {-carotene in THF ( } 6.3 \\
\mathrm{mg} / \mathrm{mL}) \text { to yield } \\
10 \mu \mathrm{M}-20 \mu \mathrm{M} \\
\text { carotenoid concentration }\end{array}$ & $\begin{array}{l}\text { Oxygen tension was a significant } \\
\text { factor of } \beta \text {-carotene antioxidant } \\
\text { efficiency. Lipid peroxidation rate } \\
\text { increased } 2.2 \text {-fold and } 1.8 \text {-fold at } \\
\quad 760 \mathrm{~mm} \mathrm{Hg} \mathrm{pO} 2\end{array}$ & [134] \\
\hline DNA damage & $\begin{array}{l}\text { HT29; xanthine/xanthine oxidase; } \\
\text { oxidation of DNA and } \\
\text { membrane integrity }\end{array}$ & $\begin{array}{l}\text { Lycopene, } \beta \text {-carotene } \\
\text { in THF to yield } \\
1-10 \mu \mathrm{M} \text { concentration }\end{array}$ & $\begin{array}{l}\text { Protection of oxidatively-induced } \\
\text { DNA damage and membrane } \\
\text { integrity Mean relative tail } \\
\text { moment was reduced a } 50 \% \text { at } \\
2.5 \mu \mathrm{M} \text { carotenoid concentration }\end{array}$ & [135] \\
\hline
\end{tabular}


Table 5. Cont.

\begin{tabular}{|c|c|c|c|c|}
\hline Experimental Approach & $\begin{array}{c}\text { Cell Model; Induction of } \\
\text { Oxidative Stress; Biomarker(s) }\end{array}$ & Carotenoids & Observed Effect & Reference \\
\hline Lipid peroxidation and DNA damage & $\begin{array}{c}\text { CV1-P monkey cells; ferric } \\
\text { nitrolotriacetate plus ascorbate; } \\
\text { lipid peroxidation (TBARS) and } \\
\text { 8-oxodGuo }\end{array}$ & $\begin{array}{l}\text { Lycopene in THF } \\
\text { to yield } \\
3 \mathrm{mM} \text { concentration }\end{array}$ & $\begin{array}{c}\text { Protection of mammalian cells } \\
\text { against membrane and DNA } \\
\text { damage. A } 77 \% \text { reduction in } \\
\text { 8-oxodGuo level in } \\
\text { lycopene-treated cells }\end{array}$ & [136] \\
\hline Lipid peroxidation and DNA damage & $\begin{array}{c}\text { Hs68 human foreskin fibroblasts; } \\
\text { AAPH and AMVN and ferric } \\
\text { nitrilotriacetate; lipid } \\
\text { peroxidation, 8-OH-dG, } \\
\text { comet assay }\end{array}$ & $\begin{array}{l}\text { Lycopene, } \beta \text {-carotene } \\
\text { in THF to yield } 10 \text { or } \\
20 \mu \mathrm{M} \text { concentration }\end{array}$ & $\begin{array}{l}\text { Both carotenoids performed } \\
\text { antioxidant and pro-oxidant } \\
\text { actions depending on the source } \\
\text { of oxidative damage }\end{array}$ & [137] \\
\hline UVA-photoprotection & $\begin{array}{c}\text { Human skin fibroblasts; UVA } \\
\text { radiation; metalloprotease } \\
1 \text { mRNA }\end{array}$ & $\begin{array}{l}\text { Lycopene, } \beta \text {-carotene } \\
\text { (nanoparticle } \\
\text { formulation) }\end{array}$ & $\begin{array}{l}\text { Reduction of the biomarker was } \\
\text { only observed in the presence of } \\
\text { vitamin E. Only a small induction } \\
\text { of HO- } 1 \text { was observed (1-2-fold) } \\
\text { for lycopene or } \\
\beta \text {-carotene treatments }\end{array}$ & [138] \\
\hline Cellular membrane oxidation & $\begin{array}{l}\text { Rat pheochromocytoma PC-12; } \\
\text { deprivation of essential nutrients; } \\
\text { peroxidation of membrane lipids } \\
\text { and SOD activity }\end{array}$ & Crocin $(0.1-10 \mu \mathrm{M})$ & $\begin{array}{l}\text { Crocin was able to function as a } \\
\text { chain-breaking antioxidant, } \\
\text { restoring SOD activity ( } 54 \% \text { of the } \\
\text { normal values) and maintained } \\
60 \% \text { of the neuron morphology }\end{array}$ & [139] \\
\hline Oxidative stress of photoreceptors & $\begin{array}{l}\text { Culture of rat retinal neurons; } \\
\text { induced oxidative stress by } \\
\text { paraquat and } \mathrm{H}_{2} \mathrm{O}_{2} \text {; apoptosis, } \\
\text { mitochondrial membrane } \\
\text { potential, cytochrome } c \\
\text { translocation, } \\
\text { and opsin expression }\end{array}$ & $\begin{array}{l}\text { Lutein, zeaxanthin and } \\
\beta \text {-carotene in } 0.05 \% \\
\text { Tween solution }\end{array}$ & $\begin{array}{l}\text { Carotenoids reduced the } \\
\text { oxidative-stress-induced } \\
\text { apoptosis as well as the other } \\
\text { evaluated biomarkers. } \\
\text { The } 2.5 \text {-fold increase in } \\
\text { photoreceptor cell death was } \\
\text { suppressed in } \\
\text { carotenoid-treated cells }\end{array}$ & [140] \\
\hline Hydrogen peroxide damage & $\begin{array}{c}\text { Rat erythrocytes (ex vivo); } \\
\text { hydrogen-induced hemolysis; } \\
\text { lipid peroxidation of membrane }\end{array}$ & $\begin{array}{l}\text { Peel extracts of unripe } \\
\text { and ripe mango fruits } \\
\text { containing carotenoids. } \\
5-25 \mu g \text { of gallic acid } \\
\text { equivalent in PBS }\end{array}$ & $\begin{array}{c}\text { Protection against membrane } \\
\text { protein degradation and } \\
\text { morphological changes. } 50 \% \\
\text { hemolysis inhibition was obtained } \\
\text { at } 11.5-20.9 \mu \mathrm{g} \mathrm{GAE}\end{array}$ & [141] \\
\hline UVA-photoprotection & $\begin{array}{l}\text { Human dermal fibroblasts; UVA } \\
\text { radiation; reactive oxygen species, } \\
\text { apoptosis cascade enzymes, heme } \\
\text { oxygenase expression }\end{array}$ & $\begin{array}{c}\text { Astaxanthin, } \\
\text { canthaxanthin, and } \\
\beta \text {-carotene in THF to } \\
\text { yield } 0.5-10 \mu \mathrm{M} \\
\text { concentration }\end{array}$ & $\begin{array}{l}\text { Astaxanthin exerted a higher } \\
\text { protective effect towards } \\
\text { photo-oxidative damage. } \\
\text { Measured ROS decreased by } 30 \% \\
\text { and } 50 \% \text { in cells treated with } \\
\text { astaxanthin at } 5 \mu \mathrm{M}\end{array}$ & [142] \\
\hline $\begin{array}{l}\text { Functional integrity and } \\
\text { mitochondrial redox state }\end{array}$ & $\begin{array}{l}\text { Transfected HeLa human cervical } \\
\text { cancer cells; hydrogen peroxide; } \\
\text { redox-sensitive fluorescent } \\
\text { protein imaging recording, } \\
\text { mitochondrial membrane } \\
\text { potential, superoxide levels }\end{array}$ & $\begin{array}{l}\text { Astaxanthin in DMSO } \\
\text { to yield } 800 \mathrm{nM} \\
\text { concentration }\end{array}$ & $\begin{array}{l}\text { Reduction of basal oxidative } \\
\text { stress, maintenance of } \\
\text { mitochondrial membrane } \\
\text { potential, improvement of the } \\
\text { mitochondrial redox state }\end{array}$ & [143] \\
\hline Mitochondrial function & $\begin{array}{l}\text { Human HepG2 cells; carotenoid } \\
\text { induction of ROS; ROS observed } \\
\text { by fluorescence microscopy }\end{array}$ & $\begin{array}{l}\text { Zeaxanthin, lutein and } \\
\text { their 3-dehydro- } \\
\text { derivatives }\end{array}$ & $\begin{array}{l}\text { Mitochondrial } \\
\text { carotenoid-oxygenase degraded } \\
\text { carotenoids to protect the } \\
\text { organelle functionality }\end{array}$ & [131] \\
\hline Retinal degeneration & $\begin{array}{l}\text { Mouse retinal ganglion cells RGC } \\
\text { 5; tunicamycin, hydrogen } \\
\text { peroxide; cell death, apoptosis } \\
\text { cascade enzymes, nuclear } \\
\text { layer thickness }\end{array}$ & $\begin{array}{c}\text { Crocetin }(0.1 \% \text { in } \\
\text { DMSO/PBS) to yield } \\
0.1-3 \mu \mathrm{M} \text { concentration }\end{array}$ & $\begin{array}{l}\text { Protective effects against retinal } \\
\text { damage. Crocetin increased the } \\
\text { protective effect against cell } \\
\text { damage 5-fold }\end{array}$ & [144] \\
\hline $\begin{array}{c}\text { Photoprotective effect against } \\
\text { UVB light }\end{array}$ & $\begin{array}{c}\text { CCD-1064Sk human dermal } \\
\text { fibroblasts; UVB irradiation; } \\
\text { comet assay, UVB-induced } \\
\text { cellular apoptosis }\end{array}$ & $\begin{array}{l}\text { Capsanthin, } \\
\text { capsorubin in THF/FBS } \\
\text { to yield } 1 \mu \mathrm{M} \\
\text { concentration }\end{array}$ & $\begin{array}{l}\text { The tested carotenoids decreased } \\
\text { markers for UVB-induced } \\
\text { apoptosis and interfered with } \\
\text { cellular responses activated by } \\
\text { UVB-mediated damage. DNA } \\
\text { damage was decreased by } 50 \% \text { in } \\
\text { capsanthin/capsorubin-treated } \\
\text { cells after UVB irradiation }\end{array}$ & [145] \\
\hline
\end{tabular}

Abbreviations: MDA: malondialdehyde; THF: tetrahydrofuran; PBS: phosphate-buffered saline; DMSO: dimethyl sulfoxide; FBS: fetal bovine serum.

\section{Antioxidant Capacity of Chlorophylls}

This section summarizes the scientific evidence that supports the antioxidant properties of different chlorophyll compounds, emphasizing issues that arise in the diverse environments where chlorophylls could exert this role. However, the one exception to this attribute is the reported pro-oxidant activity of chlorophylls in lipophilic environments under light conditions [146], where positive results have also been obtained [147]. With this exception, previous reviews described different aspects of the antioxidant capacity of chlorophylls [148-152], but we compiled the research formulated from diverse perspectives starting with the fundamental studies of the antioxidant capacity of chlorophyll 
standards, through the search of new sources of dietary antioxidants, to the ongoing studies of the in vivo chlorophyll antioxidant actions. However, in contrast to the carotenoid studies, knowledge is limited regarding the yield of chlorophyll metabolites, their absorption and transportation processes, their metabolic pathways, and their precise oxidation mechanisms. At the in vitro level, only few researchers have studied the stability of chlorophylls during digestion [153-157] and subsequent absorption through intestinal cells $[153-155,157,158]$. The major outcome is that chlorophylls $a$ and $b$ are transformed into their corresponding pheophorbides and pheophytins and are absorbed at similar rates as carotenoids. A further step has been to show that pheophorbide $a$ is transported at the intestinal level by a protein-mediated mechanism, with scavenger receptor class B type 1 (SR-BI) being a plausible transporter [159]. These results have been confirmed at the in vivo level, using mice as the experimental model, showing a preferential accumulation of pheophorbide in the liver along with multiple other chlorophyll compounds [159]. However, in humans, a trial was developed with copper chlorophylls, identifying copper chlorophyll e4 as the major component in serum [160]. In spite of this promising result, knowledge regarding chlorophyll assimilation is still scarce. In parallel, the number of studies considering the in vitro oxidation activities of chlorophylls is low compared to those examining carotenoids. However, a new and promising set of assays showing the health-promoting activities of chlorophylls has promoted the development of studies dealing with their in vivo antioxidant actions. This research area provides opportunities for unraveling chlorophylls' actions in animal metabolism.

\subsection{Different Chlorophyll Standards}

Chlorophylls are cyclic tetrapyrroles carrying a characteristic isocyclic five-membered ring (Figure 3), which show different functional groups in constrained positions, yielding more than 100 different structures present in nature. However, the antioxidant properties of chlorophylls have been studied with the most common chlorophyll derivatives, which are depicted in Figure 3, highlighting the main substituted positions $\left(\mathrm{C} 7, \mathrm{C}^{2} 3^{2}, \mathrm{C}^{3} 7^{3}\right.$, and the central metal). Starting from chlorophyll $a$, the replacement of the methyl group by an aldehyde at $\mathrm{C} 7$ forms $b$-series chlorophylls; the central magnesium can be exchanged by hydrogen (pheophytins) or metal ions such as copper, zinc, or iron (generating the metallo-chlorophylls); the additional desesterification of the phytyl group $\left(\mathrm{C}_{20} \mathrm{H}_{40}\right)$ at $\mathrm{C} 17^{3}$ creates pheophorbides; and the loss of the carboxymethyl group at $\mathrm{C}^{2} 3^{2}$ generates pyro-derivatives. The structure and configuration of chlorophylls affect their antioxidant activity, and hence different studies have addressed this question. The first step was to elucidate the differences between $a$ and $b$ series, and contradictory results were reported for $a$ and $b$ chlorophylls (Table 6). For example, some reports $[149,161,162]$ found that $b$-series chlorophyll compounds exhibit higher antioxidant activity than $a$-series ones, suggesting an unknown role for the aldehyde group at $\mathrm{C} 7$ in the antioxidant ability. Conversely, with similar tests, assays from Schwartz and colleagues [148] showed chlorophyll $a$ to be three times more effective of a radical quencher than chlorophyll $b$, in agreement with previous results reported with the ferric-nitrilotriacetate-induced singlet oxygen lipid peroxidation assay [163] or by the CUPRAC assay [37].

Unlike the influence of the $a / b$-series factor in the antioxidant action, and independent of the method applied, consensus exists on the positive role of the central metal [148,149,164,165]. Metal-free chlorophyll derivatives (pheophytins, pheophorbides, etc.) exhibit significantly lower antiradical capacity than metallo-derivatives, with the presence of copper being more favorable than zinc or magnesium. It has been hypothesized $[148,157]$ that the presence of the metal could increase the electron density at the center of the skeleton, thereby enhancing the ability of the conjugated porphyrin backbone to donate electrons. An additional explanation is based on the ability of the $\pi$-cation radical in the porphyrin structure to induce the donation of electrons from the porphyrin structure in order to break the propagation of the radical chain process [166]. However, some authors, finding a higher antioxidant capacity in pheophorbides than in metallo-chlorophylls, speculated that nonmetal chlorophylls might exert their antioxidative capacity via their inherent ion-chelation capacity in addition to the porphyrin stabilization of ROS [162]. 

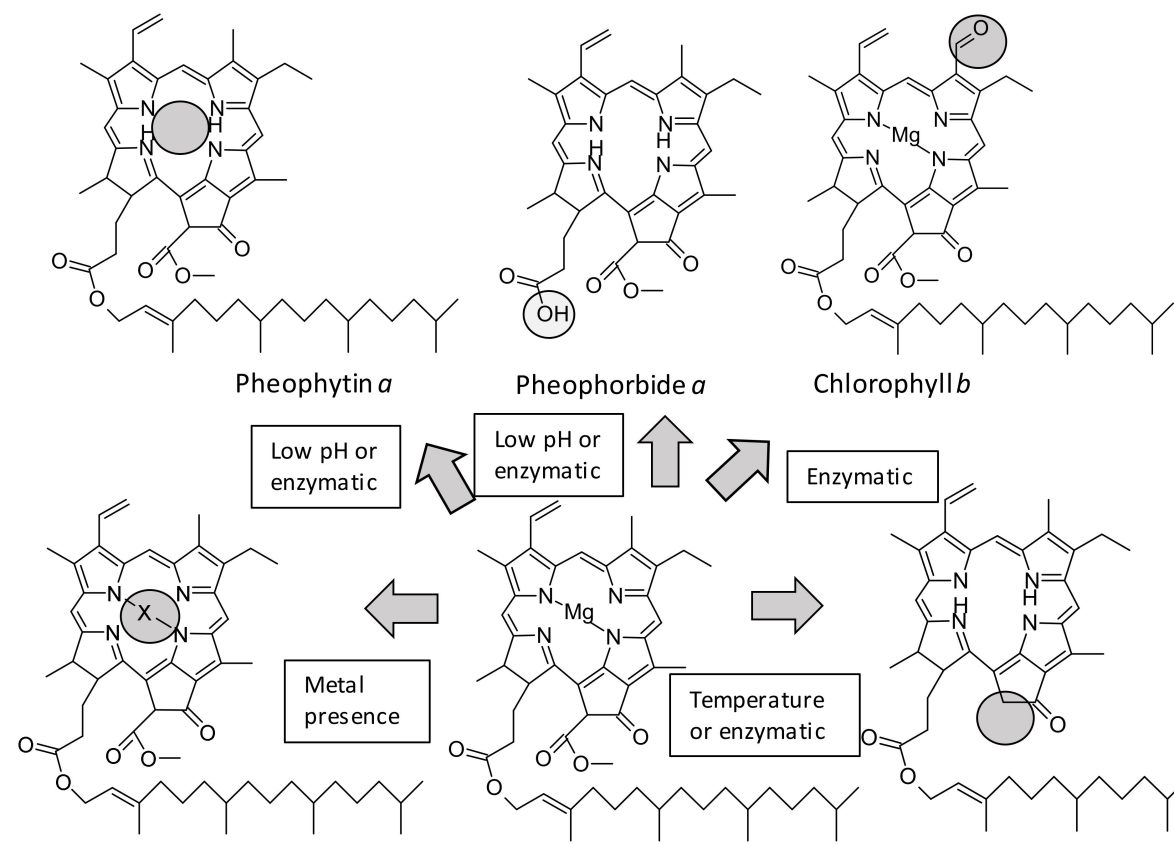

Low $\mathrm{pH}$ or

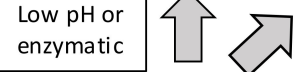

Chlorophyllb

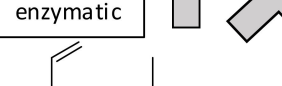

Enzymatic

Metallo-pheophytins $\left(\mathrm{X}=\mathrm{Cu}^{+2}, \mathrm{Zn}^{+2}, \mathrm{Fe}^{+2}\right)$

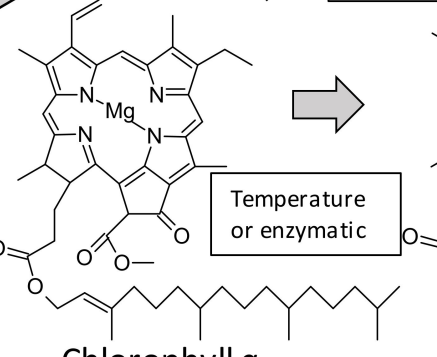

Chlorophyll $a$

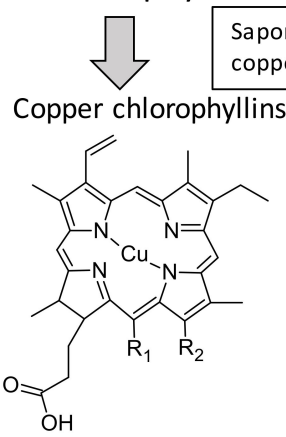

Saponification and

per addition

Pyro pheophytin $a$

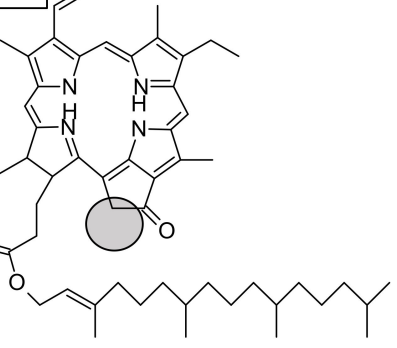

(Py

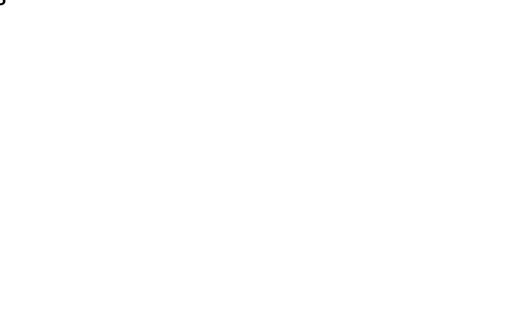

Lopper-chlorin $e_{4}$

Copper-chlorin $e_{6}$

Copper-chlorin $e_{4}$ ethyl ester
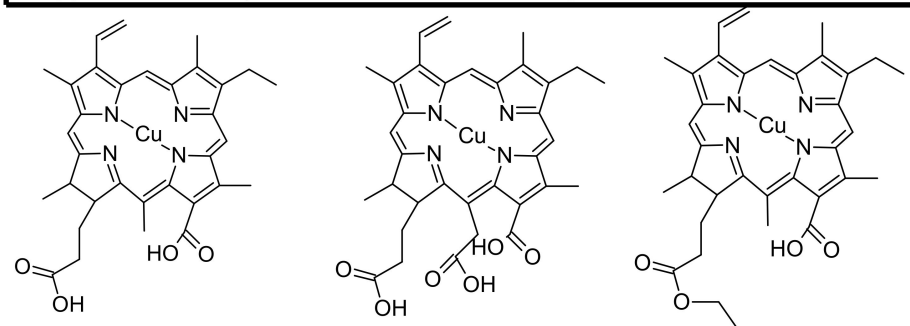

Figure 3. Chlorophyll structures cited in this paper.

Along this line, the wrongly denominated "copper chlorophyllins" (or even, sodium copper chlorophyllins (SCCs)) demand special attention. These compounds constitute the hydrophilic green food colorant (E-141ii) commonly used in ice cream, candies, cookies, and desserts [167]. They are produced from native chlorophylls after a solvent-saponification reaction and copper addition, producing a highly stable food colorant. This commercial product is formed by a diverse array of copper chlorophyll structures characterized by the lack of phytol at $\mathrm{C} 17^{3}$; they mostly present the ring $\mathrm{V}$-opened with multiple functional groups $\left(\mathrm{R}_{1}\right.$ and $\mathrm{R}_{2}$, Figure 3$)$. Apart from their attractive coloring properties, this set of chlorophyll derivatives consistently exhibit the highest antioxidant activities, as much as three to five times higher compared with their un-coppered counterparts [148]. The same outcome was obtained through different in vitro analytical methods, including DPPH [168], ABTS [148], and $\beta$-carotene test, based on the quantification of $\beta$-carotene decoloration due to the radicals generated during the oxidation of fatty acids [149]. This capacity has been positively determined through the 
noted in vivo assays, such as the comet protocol or biomarkers such as MDA, in incubated human blood cells oxidized with $\gamma$-radiation [169], demonstrating the oxidative protection of copper chlorophyllins.

Table 6. Review of in vitro antioxidant activity measured for different free chlorophylls.

\begin{tabular}{|c|c|c|c|c|}
\hline Method & Pigment & Concentration & Activity & Reference \\
\hline \multirow{6}{*}{$\begin{array}{l}\beta \text {-carotene bleaching (\% } \\
\text { inhibition of oxidation) }\end{array}$} & Cu-chlorophyllin & \multirow{6}{*}{$681 \mu \mathrm{M}$} & $80 \%$ & \multirow{6}{*}{ [149] } \\
\hline & Pheophorbide $b$ & & $80 \%$ & \\
\hline & Pheophytin $b$ & & $75 \%$ & \\
\hline & Pheophorbide $a$ & & $75 \%$ & \\
\hline & Chlorophyll $a$ & & $40 \%$ & \\
\hline & Pheophytin $a$ & & $70 \%$ & \\
\hline \multirow{3}{*}{$\beta$-carotene bleaching } & Chlorophyll & \multirow{3}{*}{$0.05 \mu \mathrm{g} / \mu \mathrm{L}$} & $49.63 \%$ & \multirow{3}{*}{ [165] } \\
\hline & Pheophytin & & $13.44 \%$ & \\
\hline & Zn-pheophytin & & $66.43 \%$ & \\
\hline \multirow{3}{*}{$\beta$-carotene bleaching } & Zn-chlorophyllin & \multirow{3}{*}{$5 \mathrm{mg} / \mathrm{mL}$} & $82.00 \%$ & \multirow{3}{*}{ [170] } \\
\hline & $\mathrm{Cu}$-chlorophyllin & & $74.40 \%$ & \\
\hline & Iron-chlorophyllin & & $90.20 \%$ & \\
\hline \multirow{6}{*}{$\begin{array}{c}\text { DPPH } \\
\text { (\% radical scavenging) }\end{array}$} & Cu-chlorophyllin & $1 \mathrm{mM}$ & $39 \%$ & \multirow{6}{*}{ [149] } \\
\hline & Pheophorbide $b$ & $1 \mathrm{mM}$ & $<12 \%$ & \\
\hline & Pheophytin $b$ & $1 \mathrm{mM}$ & $<12 \%$ & \\
\hline & Pheophorbide $a$ & $1 \mathrm{mM}$ & $<12 \%$ & \\
\hline & Chlorophyll $a$ & $1 \mathrm{mM}$ & $<12 \%$ & \\
\hline & Pheophytin $a$ & & $<12 \%$ & \\
\hline \multirow{4}{*}{ DPPH } & Pheophytin $a$ & $200 \mu \mathrm{M}$ & $55 \%$ & \multirow{4}{*}{ [171] } \\
\hline & Pheophytin $b$ & $200 \mu \mathrm{M}$ & $50 \%$ & \\
\hline & Chlorophyll $a$ & $200 \mu \mathrm{M}$ & $40 \%$ & \\
\hline & Chlorophyll $b$ & $200 \mu \mathrm{M}$ & $44 \%$ & \\
\hline \multirow{3}{*}{ DPPH } & Chlorophyll & \multirow{3}{*}{$0.05 \mu \mathrm{g} / \mu \mathrm{L}$} & $13.89 \%$ & \multirow{3}{*}{ [165] } \\
\hline & Pheophytin & & $13.44 \%$ & \\
\hline & Zn-pheophytin & & $66.43 \%$ & \\
\hline \multirow{3}{*}{ DPPH } & Zn-chlorophyllin & \multirow{3}{*}{$5 \mathrm{mg} / \mathrm{mL}$} & $37.90 \%$ & \multirow{3}{*}{ [170] } \\
\hline & $\mathrm{Cu}$-chlorophyllin & & $93.50 \%$ & \\
\hline & Fe-chlorophyllin & & $26.50 \%$ & \\
\hline \multirow{16}{*}{$\begin{array}{l}\text { DPPH } \\
\text { (TEAC) }\end{array}$} & Pyropheophytin $a$ & & 0.02 & \\
\hline & Pheophytin $a$ & & 0.04 & \\
\hline & Pheophytin $b$ & & 0.05 & \\
\hline & Chlorophyll $b$ & & 0.06 & \\
\hline & Zn-Pheophytin $b$ & & 0.13 & \\
\hline & Chlorophyll $a$ & & 0.19 & \\
\hline & Pheophorbide $a$ & & 0.21 & \\
\hline & Chlorin $e_{4}$ & $100 \mathrm{mM}$ & 0.26 & [148] \\
\hline & Zn-Pyropheophytin $a$ & $100 \mathrm{~min}$ & 0.44 & {$[140]$} \\
\hline & Zn-Pheophytin $a$ & & 0.51 & \\
\hline & Chlorin $e_{6}$ & & 0.6 & \\
\hline & Cu-Chlorin & & 0.81 & \\
\hline & $\mathrm{Cu}$-Pheophorbide $a$ & & 0.98 & \\
\hline & $\mathrm{Cu}$-Pheophytin $a$ & & 0.99 & \\
\hline & Crude SCC & & 1.04 & \\
\hline & $\mathrm{Cu}-\mathrm{Chlorin} e_{6}$ & & 2.88 & \\
\hline & Pheophorbide $a$ & & $120 \mu \mathrm{M}$ & \\
\hline & Pheophorbide $b$ & & $75 \mu \mathrm{M}$ & \\
\hline DPPH & Chlorophyllin & & $360 \mu \mathrm{M}$ & [149] \\
\hline$\left(1_{50}\right)$ & Chlorophyllide $a$ & & $>800 \mu \mathrm{M}$ & \\
\hline & Chlorophyllide $b$ & & $>800 \mu \mathrm{M}$ & \\
\hline $\mathrm{DPPH}\left(\mathrm{EC}_{50}\right)$ & Chlorin $e_{6}$ & & $23 \mu \mathrm{g} / \mathrm{mL}$ & [162] \\
\hline $\mathrm{ABTS}\left(\mathrm{EC}_{50}\right)$ & Chlorin $e_{6}$ & & $52 \mu \mathrm{g} / \mathrm{mL}$ & [172] \\
\hline ORAC (TEAC) & Chlorin $e_{6}$ & $12.5 \mu \mathrm{g} / \mathrm{mL}$ & $27 \mu \mathrm{M}$ & [172] \\
\hline
\end{tabular}


Table 6. Cont.

\begin{tabular}{|c|c|c|c|c|}
\hline Method & Pigment & Concentration & Activity & Reference \\
\hline ABTS (TEAC) & $\begin{array}{c}\text { Pheophytin } a \\
\text { Pheophytin } b \\
\text { Pyropheophytin } a \\
\text { Chlorophyll } b \\
\text { Zn-pheophytin } b \\
\text { Zn-pheophytin } a \\
\text { Pheophorbide } a \\
\text { Chlorin } e_{4} \\
\text { Cu-pheophytin } a \\
\text { Chlorin } e_{6} \\
\text { Zn-pyropheophytin } a \\
\text { Chlorophyll } a \\
\text { Crude SCC } \\
\text { Cu-chlorin } e_{4} \\
\text { Cu-chlorin } e_{6} \\
\text { Cu-pheophorbide }\end{array}$ & $100 \mathrm{mM}$ & $\begin{array}{l}0.02 \\
0.08 \\
0.16 \\
0.23 \\
0.29 \\
0.43 \\
0.45 \\
0.53 \\
0.58 \\
0.64 \\
0.67 \\
0.73 \\
1.25 \\
1.35 \\
2.25 \\
2.4\end{array}$ & [148] \\
\hline $\begin{array}{l}\text { TBARS } \\
\text { Kidney }\end{array}$ & Chlorophyll $b$ & $\begin{array}{l}0.2 \mathrm{mg} / \mathrm{kg} \text { b.w. } \\
0.5 \mathrm{mg} / \mathrm{kg} \text { b.w. }\end{array}$ & $\begin{array}{l}61.16 \mathrm{nmol} / \mathrm{g} \\
62.06 \mathrm{nmol} / \mathrm{g}\end{array}$ & [173] \\
\hline $\begin{array}{l}\text { TBARS } \\
\text { Liver }\end{array}$ & Chlorophyll $b$ & $\begin{array}{l}0.2 \mathrm{mg} / \mathrm{kg} \text { b.w. } \\
0.5 \mathrm{mg} / \mathrm{kg} \text { b.w. }\end{array}$ & $\begin{array}{l}41.29 \mathrm{nmol} / \mathrm{g} \\
45.90 \mathrm{nmol} / \mathrm{g}\end{array}$ & [173] \\
\hline Comet assay & $\begin{array}{l}\text { Pheophytin } a \\
\text { Pheophytin } b \\
\text { Chlorophyll } a \\
\text { Chlorophyll } b\end{array}$ & $\begin{array}{l}50 \mu \mathrm{M} \\
50 \mu \mathrm{M} \\
50 \mu \mathrm{M} \\
50 \mu \mathrm{M}\end{array}$ & $\begin{array}{l}3500 \\
3500 \\
4000 \\
4000\end{array}$ & [171] \\
\hline Fe chelation & $\begin{array}{l}\text { Pheophytin } a \\
\text { Pheophytin } b \\
\text { Chlorophyll } a \\
\text { Chlorophyll } b\end{array}$ & $\begin{array}{l}200 \mu \mathrm{M} \\
200 \mu \mathrm{M} \\
200 \mu \mathrm{M} \\
200 \mu \mathrm{M}\end{array}$ & $\begin{array}{l}65 \% \\
65 \% \\
55 \% \\
55 \% \\
\end{array}$ & [171] \\
\hline Lipid peroxidation & $\begin{array}{l}\text { Pheophytin } a \\
\text { Pheophytin } b \\
\text { Chlorophyll } a \\
\text { Chlorophyll } b\end{array}$ & $\begin{array}{l}100 \mu \mathrm{M} \\
100 \mu \mathrm{M} \\
100 \mu \mathrm{M} \\
100 \mu \mathrm{M}\end{array}$ & $\begin{array}{l}75 \% \\
65 \% \\
95 \% \\
75 \% \\
\end{array}$ & [171] \\
\hline $\begin{array}{l}\text { ROO. scavenging capacity } \\
\text { ( } \alpha \text {-tocopherol relative) }\end{array}$ & $\begin{array}{l}\text { Chlorophyll } a \\
\text { Chlorophyll } b\end{array}$ & & $\begin{array}{l}308 \\
386\end{array}$ & [171] \\
\hline $\begin{array}{l}\text { Comet assay } \\
\text { (Tail moment) }\end{array}$ & $\begin{array}{l}\text { Cu-chlorophyllin } \\
\text { Chlorophyllide } a \\
\text { Chlorophyllide } b \\
\text { Pheophorbide } a \\
\text { Pheophorbide } b\end{array}$ & $\begin{array}{l}20 \mu \mathrm{M} \\
20 \mu \mathrm{M} \\
20 \mu \mathrm{M} \\
20 \mu \mathrm{M} \\
20 \mu \mathrm{M}\end{array}$ & $\begin{array}{c}138 \\
136 \\
126 \\
100 \\
91\end{array}$ & [172] \\
\hline 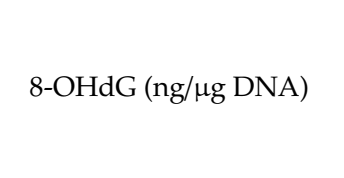 & $\begin{array}{l}\text { Cu-chlorophyllin } \\
\text { Chlorophyllide } a \\
\text { Chlorophyllide } b \\
\text { Pheophorbide } a \\
\text { Pheophorbide } b\end{array}$ & $\begin{array}{l}20 \mu \mathrm{M} \\
20 \mu \mathrm{M} \\
20 \mu \mathrm{M} \\
20 \mu \mathrm{M} \\
20 \mu \mathrm{M}\end{array}$ & $\begin{array}{l}0.53 \\
0.68 \\
0.79 \\
0.55 \\
0.62\end{array}$ & [172] \\
\hline
\end{tabular}

Abbreviations: SCC: sodium copper chlorophyllins; b.w.: body weight; TEAC: Trolox-equivalent antioxidant capacity; $\mathrm{I}_{50}$ : inhibitor concentration that causes $50 \%$ of inhibition; $\mathrm{EC}_{50}$ : compound concentration that gives half-maximal response; TBARS: thiobarbituric acid-reactive substances assay; 8-OHdG: 8-hydroxy-2-deoxyguanosine.

\subsection{Antioxidant Activity of Chlorophyll Extracts from Different Sources}

The knowledge of the antioxidant competence of purified molecules constitutes the first and fundamental step that should be pursued. However, we must remember that the real scenarios in which these molecules exert their actions are intricate environments with multiple interactions. Foods should be considered complex matrices, where the isolation of each compound could be challenging despite synergies or antagonisms [2] with other compounds, effects that are not observed when the antioxidant activity is measured using a pure standard. Hence, analyzing the antioxidant capacity of chlorophylls from another perspective would involve studying complete foods, organisms, or extracts. 
However, for this approach, a battery of antioxidant assays based on different reaction mechanisms should be applied instead of a single assay as the best strategy to obtain accurate results. In this sense, these main topics should be considered when analyzing food products [2], selecting a method, or evaluating the obtained results: the working $\mathrm{pH}$, a wide range of hydro-lipophilicity, kinetics of the main antioxidants, the base color of the food, and the relative amount of proteins.

The seaweed industry has an annual value of USD \$5.5-6 billion, with $90 \%$ of the production being for human food products, mainly for their high nutritional value. Chlorophylls are among the secondary metabolites responsible for the health benefits of seaweed consumption. For example, five brown species of seaweed are able to scavenge peroxyl radicals due to their chlorophyll $a$ content, which shows a synergistic effect with vitamin E [174]. However, Chlorophyceae (green seaweeds) are the most investigated species [175]. Enteromorpha prolifera has excellent antioxidant properties with strong DPPH-radical-scavenging activity, reducing power, and hydroxyl-radical-scavenging activity due to their pheophorbide $a$ content [176].

Spirulina has recently been approved as a food, opening the door to new food formulations enriched with different microalgae. For example, the dried biomasses of four microalgae strains, Arthrospira platensis, Chlorella vulgaris, Tetraselmis suecica, and Phaeodactylum tricornutum, were used to prepare wheat crackers [177]. The authors reported that higher amounts of microalgae increased the antioxidant capacity measured via the DPPH method. Accordingly, pasta enriched with microencapsulated Spirulina increased the antioxidant potential after cooking [178]. Using a different method, namely the peroxyl-radical-scavenging assay, the chlorophyll fraction in Phormidium autumnale was found to be responsible for a high antioxidant activity, around 200 times more potent than $\alpha$-tocopherol [171].

Another line of research is the analysis of plant extracts to identify rich sources of edible antioxidants. For example, the chlorophyll content ( $a$ and $b$ ) of stem amaranth (Amaranthus lividus) leaves has a significant positive correlation with the total antioxidant content (measured through DPPH and ABTS methods) [179], indicating this leafy vegetable as a potential source of antioxidants in the human diet. Several medicinal plants show high antioxidant capacity, some of them at the same level as ascorbic acid [180]. Elimination of chlorophylls from different cultivars of jalapeño and serrano peppers drastically reduced the antioxidant activity estimated by the DPPH-scavenging assay and measured by electron-paramagnetic resonance (EPR) spectroscopy [181]. This antioxidant action was also observed in vivo. Chlorophyll extracts from Sauropus androgynous (L.) leaves intraperitoneally administered to Wistar rats for 14 days were able to protect the liver and kidney from the oxidative stress caused by sodium nitrate [182].

Despite their functional properties, the use of chlorophyll as a functional ingredient has been limited to some extent due to its chemical instability. To address this, a new approach was constructed, using different microencapsulation techniques as a strategy to retard chlorophyll oxidation, enhance water solubility, improve stability, and extend shelf life. For example, kale chlorophylls were microencapsulated in isolated whey protein, which increased their antioxidant activity $20 \%$ as assessed through the DPPH method [183].

\subsection{In Vivo Antioxidant Activity of Chlorophylls}

Multiple biological functions have been reported for chlorophylls. The most known is probably the ability to trap mutagens based on the planar structure of chlorophylls, which allows the availability of deleterious compounds in the cell to be reduced [170]. Strictly related to their antioxidant capabilities, two main mechanisms can be described: their direct free-radical-scavenging activity and the metabolic activation of detoxification pathways.

\subsubsection{In Vivo Free-Radical-Scavenging Properties of Chlorophylls}

Regarding the first mechanism, Figure 4 describes the process of formation and propagation of

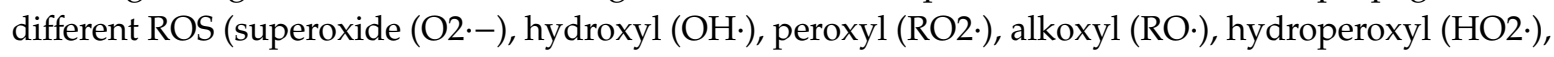


and nonradical species such as hydrogen peroxide $\left(\mathrm{H}_{2} \mathrm{O}_{2}\right)$ and singlet oxygen $\left({ }^{1} \mathrm{O}_{2}\right)$. The common experimental approach in these studies is the analysis of different tissues from experimental animals (mice, rats, etc.) subjected to diets rich in chlorophyllin (probably copper chlorophyllins). The results demonstrated the capacity of chlorophylls to reduce the general ROS levels at the in vitro level [184-187]. As stated above, excess ROS generation in cells induces damage in lipids, proteins, and DNA, making oxidized biomolecules perfect biomarkers of in vivo oxidative status. The pioneer works on the inhibition of lipid peroxidation by copper chlorophylls were developed by Sato's group [168,188]. Later, this effect was reported in numerous tissues, normally through the formation of lipid hydroperoxides [183], but also through the TBARS method: in lymphocytes in a concentration-dependent manner up to 75\% [185], in kidney and heart tissues at the same level as ascorbic acid [189], and in the liver [190-192], brain [187], and serum [182].

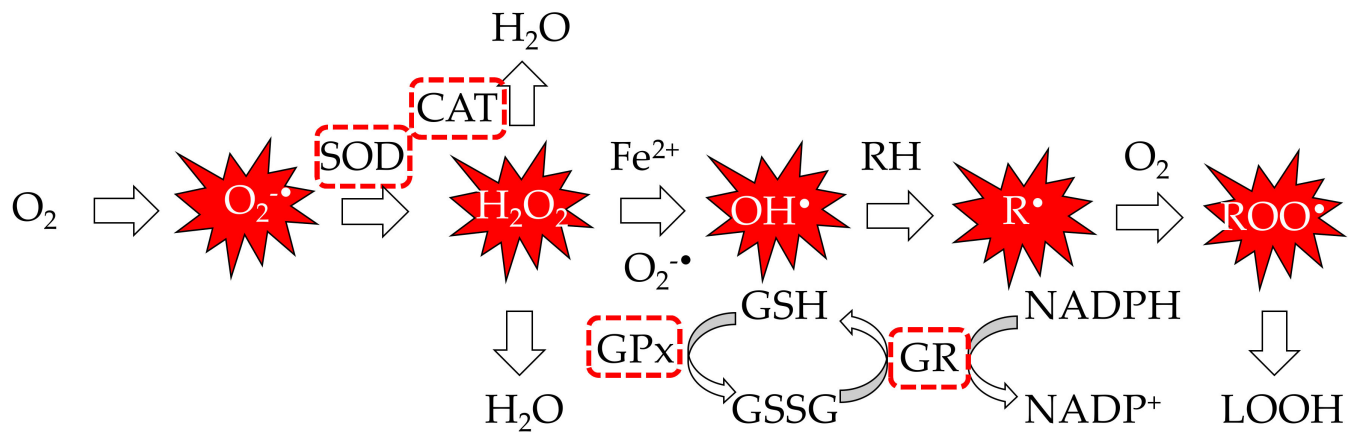

Figure 4. Reactions and enzymes involved in reactive oxygen species (ROS) generation and propagation analyzed in chlorophyll antioxidant studies: superoxide $(\mathrm{O} 2 \cdot-)$, hydroxyl $(\mathrm{OH} \cdot)$, peroxyl $\left(\mathrm{RO}_{2} \cdot\right)$, and hydrogen peroxide $\left(\mathrm{H}_{2} \mathrm{O}_{2}\right)$. Antioxidant enzymes: SOD: superoxide dismutase, CAT: catalase, GPx: glutathione peroxidase, GR: glutathione reductase, GSH/GSSG: reduced/oxidized glutathione.

ROS also react with DNA, mainly yielding base radicals through the formation of double bonds and occasionally producing deoxyribose radicals by abstracting hydrogen atoms [193]. In any case, both situations can result in strand breakage, which has been used as an oxidative biomarker to measure the antioxidant activity of chlorophylls. For example, using an in vitro plasmid DNA system, the rate constant for the reaction of OH· and 2-ROO [194] with chlorophyllin has been calculated, resulting in similar figures to other well-known antioxidants (such as GSH) and pointing to the effective role of chlorophyllin as an oxidative protector of DNA. At the in vitro level, different non-copper chlorophyll compounds (chlorophyllide $a$ and $b$ and pheophorbide $a$ and $b$ ) are able to reduce single-strand DNA breaks and levels of 8-OHdG in human lymphocytes, although pheophorbide derivatives displayed higher scavenging capacities than others. These indicators have also been determined at the in vivo level. Male rats fed a chlorophyllin diet showed lower levels of liver microsomal MDA, DNA fragmentation, restriction-fragment-length polymorphism (RFLP), and 8-OHdG concentration in comparison with a control diet [195]. As a new analytical approach, immunohistochemical techniques have been developed to allow the measurement of DNA oxidative indexes, for example to prove the capacity of chlorophyllins to reduce the formation of 8-OHdG in cancer-induced hamsters [196].

Finally, the main biomarker of oxidative stress in proteins is the formation of carbonyl (CO) groups (aldehydes and ketones), especially on Pro, Arg, Lys, and Thr residues [197]. Measuring this oxidative biomarker, copper chlorophyllin has shown its ability to decrease the level of protein carbonyls in kidney and heart tissues at rates similar to those of ascorbic acid [190] in liver tissues [184,188,192]. An even more marked effect was observed when Caenorhabditis elegans consumed a pheophorbide-rich diet, reducing the carbonyl groups up to $80 \%$ in comparison with a control group [198].

Concomitant with this capacity to reduce the level of oxidation in the main biomolecules, chlorophyll derivatives are effective enhancers of the activity of the main enzymes implicated in the antioxidant machinery at the cellular level (Figure 4). For example, mice fed 1\% chlorophyllin 
for three days in drinking water were euthanized and mitochondrial isolates from the liver were exposed to $\gamma$-rays to induce oxidative stress. Chlorophyll-treated rats were able to restore the SOD activity depressed by radiation to a greater extent in oxic compared to anoxic conditions [184]. 2,2'-Azobis(2-methylpropionamidine) dihydrochloride (AAPH)-oxidative-stress-induced mice were injected ex vivo with 100-400 mg/g body weight (b.w.) copper chlorophyllin, and the corresponding lymphocyte lysates showed increased catalase and GPx activities in comparison to control samples [185]. Hamsters with 7,12-Dimethylbenz[a]anthracene (DMBA)-induced cancer provided with a 14 week chlorophyllin-supplemented diet showed increased expression (assessed by semiquantitative RT-PCR) of SOD, catalase, and GPx enzymes, in agreement with their signals in the corresponding immunoblot analysis [197]. Diabetic mice with oxidative stress induced by streptozotocine showed activation of detoxification pathways (CuZnSOD, MnSOD, CAT, GPx, and GR) in response to alternative and intraperitoneal doses of $50 \mathrm{mg} / \mathrm{kg}$ b.w. of copper chlorophyll for 28 days in kidney, heart [190], and liver tissues [192]. More recently, diabetic Wistar rats were in situ perfused with chlorophyll-based extract or chlorophyll $a$ standard and subjected to light irradiance to induce oxidative stress. The treatment group showed lower hepatic oxidative stress, and lower expression and activity of CuZnSOD, MnSOD, CAT, and superoxide dismutase in liver tissues [188]. The next step would be to investigate the exact mechanisms by which chlorophylls activate these antioxidant enzymes.

\subsubsection{In Vivo Activation of Detoxification Pathways by Chlorophylls}

In addition to antioxidant enzymes, living cells develop programmed reactions to reduce the potential injury caused by xenobiotics through specific metabolism and later excretion. The group of enzymes involved is known as drug-metabolizing enzymes (DMEs), and their sequential function allows them to be categorized as Phase I, II, and III enzymes. Phase I enzymes oxidize drugs or xenobiotics, for example, cytochrome P450 monooxygenase (CYP), the expression of which is governed by several nuclear receptors. Phase II enzymes conjugate products of Phase I reactions, such as glutathione peroxidase (GPX), glutathione S-transferase (GST), heme oxygenase 1 (HMO-1), or NADPH quinine oxidoreductase 1 (NQO-1), among others (Figure 5). Nuclear factor erythroid 2 related factor 2 (Nrf-2) is the transcription factor considered to be the main inductor of the Phase II genes, commonly called antioxidant-response element (ARE) genes. In addition, Nrf-2 forms a complex in the cytoplasm with Keap-1 (Kelch-like epichlorohydrin-associated protein 1), which is a negative regulator of the Nrf-2/ARE pathway [199]. Phase III enzymes are responsible for the export of the final metabolites out of cells.

The first evidence of the capacity of chlorophyll compounds as inducers of mammalian Phase II cytoprotective genes was reported by Fahey et al. [200]. They measured the ability of different chlorophyll structures to induce NQO-1. Among them, chlorophyllins and, above all, copper chlorin $e_{4}$ ethyl ester (Figure 3) were the most potent inducers related to chlorophyll, pheophytin, or pheophorbide. The authors demonstrated that copper chlorin $e_{4}$ (disodium) can react with free sulfhydryl groups, suggesting that they can bind to Keap-1 and ARE to trigger Phase II gene transcription. These results were subsequently supported by a completely different approach. An evident increase in the expression of Nrf-2 and a decrease in Keap-1 were observed in the buccal pouch tissues of experimental animals when their diet was supplemented with chlorophyllins [196], in parallel with the immunohistochemical staining of their proteins. The activation of Nrf-2 was concomitant with a decrease in the expression levels of CYP1A1 and CYP1B1 (cytochrome P450 monooxygenase), Phase I genes, and induction of the expression of Phase II genes (NQO-1 and GST). NQO1 functions as a part of the oxidative-stress-induced cellular defense when GST, through reactive oxygen species, converts to glutathione. Chlorophyllin enhanced the nuclear translocation of Nrf-2 in mouse splenic lymphocytes in both a dose- and time-dependent manner [201]. In rats with breast cancer, chlorophyllin increased the GSH levels in the liver [202]. 


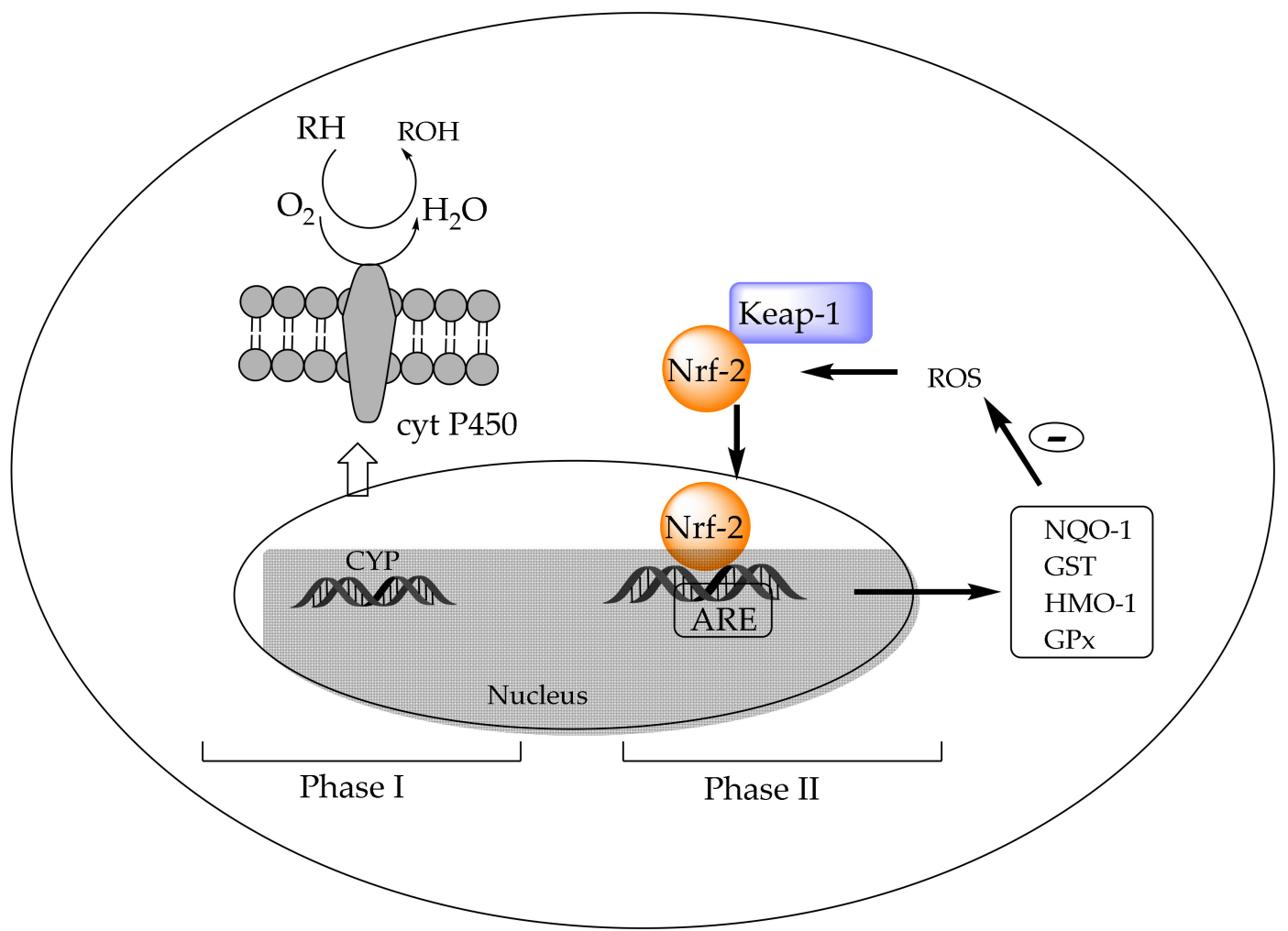

Figure 5. Detoxifying metabolism: Phase I and Phase II. CYP: cytochrome P450 monooxygenase, ARE genes: antioxidant-response elements; Nrf-2: nuclear factor erythroid 2 related factor 2; Keap-1: Kelch-like epichlorochydrin-associated protein 1; NADPH quinine oxidoreductase 1: NQO-1; glutathione S-transferase: GST; heme oxygenase 1: HMO-1; glutathione peroxidase: GPX.

Another line of research comes from the assumption that chlorophyll $a$ and its derivatives have been proposed to exert antidiabetic functions [203]. At a molecular level, chlorophyll $a$ metabolites are retinoic $\mathrm{X}$ receptors (RXRs), known to alter insulin and glucose signaling and, consequently, decrease hyperglycemia, hypertriglyceridemia, and hyperinsulinemia [204]. Evidence of chlorophyll's influence in insulin metabolism was obtained using the animal experimental model Caenorhabditis elegans [205]. Insulin ligands, through a cascade of several kinases, can inactivate the transcription factor forkhead box (DAF-16/FOXO), thereby blocking the transcription of target genes such as the SOD-3 gene [206], which codifies superoxide dismutase. Chlorophyll-treated nematodes modify the nuclear translocation of DAF-16 and increase the expression of SOD-3, increasing their lifespan by up to $25 \%$. Such anti-aging activity could be promoted by chlorophyll's enhancement of the tolerance to oxidative stress. Upon the same pro-oxidant (Juglone) treatment, the survival rate of nematodes with the chlorophyll diet increased more than $200 \%$ compared to the control group.

\section{Conclusions}

There is a primary chemical core understanding of the antioxidant behavior of carotenoids and chlorophyll pigments, but emerging pieces of evidence point to a rich diversity of actions and effects, which are intricate and distant from any antioxidant chemical nature. This is particularly true in the case of carotenoids, but chlorophylls are also being included in this concept. A fine line exists between experimental protocols and a lack of biological context of results, so the researcher should always consider the barrier between the in vitro and in vivo scenarios. Additionally, the limitations of studies, particularly those related to dosage strategies, and sources of the antioxidant (pure standard vs. food extract) should be noted. This review provides literature-based knowledge with the aim of advancing the concept of antioxidants in the near future to applications in the real world. Thus, it is 
necessary to set the average spread of reliable in vivo oxidative biomarkers with which to monitor the onset of degenerative diseases, so that the influence of dietary antioxidants could be established more precisely. A real effort from academics, research centers, and policymakers is taking shape in this line. However, we should not lose sight of the inverse association between pigment-containing fruits and vegetables with risk for various chronic diseases. It is also crucial to consider the stage of a disease at which antioxidant pigments may impact its development and progression. In this regard, it seems that carotenoids and chlorophylls have gone from being considered bioactive to becoming biomarkers of the onset of diseases related to oxidative stress. The key to continued support of the pivotal role of pigments in providing cooperative action within the antioxidant defense system is to look for metabolites arising early from imbalances of oxidative stress homeostasis. Currently available metabolomic platforms are starting to build the basis for such knowledge, which is expected to set future lines of research.

Author Contributions: Conceptualization, A.P.-G. and M.R.; resources, M.R.; writing—original draft preparation, A.P.-G., I.V., and M.R.; writing-review and editing, A.P.-G. and M.R.; visualization and supervision, A.P.-G. and M.R.; project administration, A.P.-G. and M.R.; funding acquisition, I.V. and M.R. All authors have read and agreed to the published version of the manuscript.

Funding: This work was supported by the Ministerio de Ciencia, Investigación y Universidades, Agencia Estatal de Investigación and the European Regional Development Fund (ERDF), grant number RTI2018-095415-B-I00 and AGL2017-87884-R.

Conflicts of Interest: The authors declare no conflict of interest.

\section{References}

1. Sun, Y.; Yang, C.; Tsao, R. Nomenclature and general classification of antioxidant activity/capacity assays. In Measurement of Antioxidant Activity \& Capacity: Recent Trends and Applications; Apak, R., Capanoglu, E., Shahidi, F., Eds.; John Wiley \& Sons Ltd.: Hoboken, NJ, USA, 2018; Chapter 1; pp. 1-19.

2. Capanoglu, E.; Kamiloglu, S.; Ozkan, G.; Apak, R. Evaluation of antioxidant activity/capacity measurement methods for food products. In Measurement of Antioxidant Activity \& Capacity: Recent Trends and Applications; Apak, R., Capanoglu, E., Shahidi, F., Eds.; John Wiley \& Sons Ltd.: Hoboken, NJ, USA, 2018; Chapter 13; pp. 273-286.

3. Halliwell, B. How to Characterize a Biological Antioxidant. Free Radic. Res. Commun. 1990, 9, 1-32. [CrossRef]

4. Apak, R.; Özyürek, M.; Güçlü, K.; Çapanoğlu, E. Antioxidant Activity/Capacity Measurement. 1. Classification, Physicochemical Principles, Mechanisms, and Electron Transfer (ET)-Based Assays. J. Agric. Food Chem. 2016, 64, 997-1027. [CrossRef]

5. Pellegrini, N.; Vitaglione, P.; Granato, D.; Fogliano, V. Twenty-five years of total antioxidant capacity measurement of foods and biological fluids: Merits and limitations. J. Sci. Food Agric. 2018. [CrossRef] [PubMed]

6. Munialo, C.D.; Naumovski, N.; Sergi, D.; Stewart, D.; Mellor, D.D. Critical evaluation of the extrapolation of data relative to antioxidant function from the laboratory and their implications on food production and human health: A review. Int. J. Food Sci. Technol. 2019, 54, 1448-1459. [CrossRef]

7. Cao, G.; Alessio, H.M.; Cutler, R.G. Oxygen-radical absorbance capacity assay for antioxidants. Free Rad. Biol. Med. 1993, 14, 303-311. [CrossRef]

8. Cao, G.; Prior, R.L. Measurement of oxygen radical absorbance capacity in biological samples. Methods Enzymol. 1999, 299, 50-62.

9. Frankel, E.N.; Meyer, A.S. The problem of using one-dimensional methods to evaluate multifunctional food and biological antioxidants. J. Sci. Food Agric. 2000, 80, 1925-1941. [CrossRef]

10. Karadag, A.; Ozcelik, B.; Saner, S. Review of Methods to Determine Antioxidant Capacities. Food Anal. Methods 2009, 2, 41-60. [CrossRef]

11. Ou, B.; Hampsch-Woodill, M.; Prior, R.L. Development and Validation of an Improved Oxygen Radical Absorbance Capacity Assay Using Fluorescein as the Fluorescent Probe. J. Agric. Food Chem. 2001, 49, 4619-4626. [CrossRef] 
12. Prior, R.L.; Hoang, H.; Gu, L.; Wu, X.; Bacchioca, M.; Howard, L.; Hampsch-Woodill, M.; Huang, D.; Ou, B.; Jacob, R. Assays for hydrophilic and lipophilic antioxidant capacity (oxygen radical absorbance capacity (ORACFL)) of plasma and other biological and food samples. J. Agric. Food Chem. 2003, 51, 3273-3279. [CrossRef]

13. Anderson, S.M.; Krinsky, N.I. Protective action of carotenoid pigments against photodynamic damage to liposomes. Photochem. Photobiol. 1973, 18, 403-408. [CrossRef] [PubMed]

14. Krinsky, N.I.; Deneke, S.M. Interaction of oxygen and oxy-radicals with carotenoids. J. Natl. Cancer Inst. 1982, 69, 205-210.

15. Miki, W. Biological functions and activities of animal carotenoids. Pure App. Chem. 1991, 63, 141-146. [CrossRef]

16. Hill, J.; Clarke, J.D.; Vargesson, N.; Jowett, T.; Holder, N. Exogenous retinoic acid causes specific alterations in the development of the midbrain and hindbrain of the zebrafish embryo including positional respecification of the Mauthner neuron. Mech. Dev. 1995, 50, 3-16. [CrossRef]

17. Rengel, D.; Díez-Navajas, A.; Serna-Rico, A.; Veiga, P.; Muga, A.; Milicua, J.C. Exogenously incorporated ketocarotenoids in large unilamellar vesicles. Protective activity against peroxidation. Biochim. Biophys. Acta 2000, 1463, 179-187. [CrossRef]

18. Matsushita, Y.; Suzuki, R.; Nara, E.; Yokoyama, A.; Miyashita, K. Antioxidant activity of polar carotenoids including astaxanthin- $\beta$-glucoside from marine bacterium on PC liposomes. Fisheries Sci. 2000, 66, 980-985. [CrossRef]

19. Cvetković, D.J.; Stanojević, J.; Cakić, M.; Marković, D. Investigation into the potential chemical mechanism of carotenoids pro-oxidant activity with liposomes under UV-irradiation. J. Serb. Chem. Soc. 2017, 82, 1009-1023. [CrossRef]

20. Porter, W.L. Recent trends in food applications of antioxidants. In Autoxidation in Food and Biological Systems; Simic, M.G., Karel, M., Eds.; Plenum Press: New York, NY, USA, 1980; pp. 295-365.

21. Frankel, E.N.; Huang, S.-W.; Kanner, J.; German, J.B. Interfacial phenomena in the evaluation of antioxidants: Bulk oils vs emulsion. J. Agric. Food Chem. 1994, 42, 1054-1059. [CrossRef]

22. Laguerre, M.; Bayrasy, C.; Panya, A.; Weiss, J.; McClements, D.J.; Lecomte, J.; Decker, E.A.; Villeneuve, P. What makes good antioxidants in lipid-based systems? The next theories beyond the polar paradox. Crit. Rev. Food Sci. Nutr. 2015, 55, 183-201. [CrossRef]

23. Kevers, C.; Falkowski, M.; Tabart, J.; Defraigne, J.-O.; Dommes, J.; Pincemail, J. Evolution of Antioxidant Capacity during Storage of Selected Fruits and Vegetables. J. Agric. Food Chem. 2007, 55, 8596-8603. [CrossRef]

24. Wayner, D.D.M.; Burton, G.W.; Ingold, K.U.; Locke, S. Quantitative measurement of the total, peroxyl radical-trapping antioxidant capability of human blood plasma by controlled peroxidation: The important contribution made by plasma proteins. FEBS Lett. 1985, 187, 33-37. [CrossRef]

25. Rice-Evans, C.; Miller, N.J. [241 Total antioxidant status in plasma and body fluids. In Methods in Enzymology; Elsevier: Amsterdam, The Netherlands, 1994; Volume 234, pp. 279-293. ISBN 9780121821357.

26. Mueller, L.; Boehm, V. Antioxidant Activity of $\beta$-Carotene Compounds in Different In Vitro Assays. Molecules 2011, 16, 1055-1069. [CrossRef] [PubMed]

27. Wright, J.S.; Johnson, E.R.; DiLabio, G.A.; DiLabio, G.A. Predicting the activity of phenolic antioxidants: Theoretical method, analysis of substituent effects, and application to major families of antioxidants. J. Am. Chem. Soc. 2001, 123, 1173-1183. [CrossRef] [PubMed]

28. Benzie, I.F.F.; Strain, J.J. The Ferric Reducing Ability of Plasma (FRAP) as a Measure of "Antioxidant Power": The FRAP Assay. Anal. Biochem. 1996, 239, 70-76. [CrossRef]

29. Benzie, I.F.; Strain, J.J. Ferric reducing/antioxidant power assay: Direct measure of total antioxidant activity of biological fluids and modified version for simultaneous measurement of total antioxidant power and ascorbic acid concentration. Methods Enzymol. 1999, 299, 15-27.

30. Halvorsen, B.L.; Holte, K.; Myhrstad, M.C.W.; Barikmo, I.; Hvattum, E.; Remberg, S.F.; Wold, A.-B.; Haffner, K.; Baugerød, H.; Andersen, L.F.; et al. A Systematic Screening of Total Antioxidants in Dietary Plants. Nutr. J. 2002, 132, 461-471. [CrossRef]

31. Payne, A.C.; Mazzer, A.; Clarkson, G.J.J.; Taylor, G. Antioxidant assays-Consistent findings from FRAP and ORAC reveal a negative impact of organic cultivation on antioxidant potential in spinach but not watercress or rocket leaves. Food Sci. Nutr. 2013, 1, 439-444. [CrossRef] 
32. Apak, R.; Güçlü, K.; Özyürek, M.; Karademir, S.E. Novel Total Antioxidant Capacity Index for Dietary Polyphenols and Vitamins C and E, Using Their Cupric Ion Reducing Capability in the Presence of Neocuproine: CUPRAC Method. J. Agric. Food Chem. 2004, 52, 7970-7981. [CrossRef]

33. Serafini, M.; Del Rio, D. Understanding the association between dietary antioxidants, redox status and disease: Is the Total Antioxidant Capacity the right tool? Redox Rep. 2004, 9, 145-152. [CrossRef]

34. Apak, R.; Güçlü, K.; Demirata, B.; Özyürek, M.; Çelik, S.; Bektaşoğlu, B.; Berker, K.; Özyurt, D. Comparative Evaluation of Various Total Antioxidant Capacity Assays Applied to Phenolic Compounds with the CUPRAC Assay. Molecules 2007, 12, 1496-1547. [CrossRef]

35. Prior, R.L.; Wu, X.; Schaich, K. Standardized methods for the determination of antioxidant capacity and phenolics in foods and dietary supplements. J. Agric. Food Chem. 2005, 18, 4290-4302. [CrossRef]

36. Nilsson, J.; Pillai, D.; Önning, G.; Persson, C.; Nilsson, Å.; Åkesson, B. Comparison of the 2,2'-azinobis-3-ethylbenzotiazo-line-6-sulfonic acid (ABTS) and ferric reducing anti-oxidant power (FRAP) methods to asses the total antioxidant capacity in extracts of fruit and vegetables. Mol. Nutr. Food Res. 2005, 49, 239-246. [CrossRef]

37. Sözgen Başkan, K.; Tütem, E.; Özer, N.; Apak, R. Spectrophotometric and Chromatographic Assessment of Contributions of Carotenoids and Chlorophylls to the Total Antioxidant Capacities of Plant Foods. J. Agric. Food Chem. 2013, 61, 11371-11381. [CrossRef]

38. Shalaby, E.A.; Sanaa, S.M.M. Comparison of DPPH and ABTS assays for determining antioxidant potential of water and methanol extracts of Spirulina platensis. Indian J. Mar. Sci. 2013, 42, 556-564.

39. Jiménez-Escrig, A.; Jiménez-Jiménez, I.; Pulido, R.; Saura-Calixto, F. Antioxidant activity of fresh and processed edible seaweeds: Antioxidant activity of seaweeds. J. Sci. Food Agric. 2001, 81, 530-534. [CrossRef]

40. Arnao, M.B. Some methodological problems in the determination of antioxidant activity using chromogen radicals: A practical case. Trends Food Sci. Technol. 2000, 11, 419-421. [CrossRef]

41. Böhm, V.; Puspitasari-Nienaber, N.L.; Ferruzzi, M.G.; Schwartz, S.J. Trolox Equivalent Antioxidant Capacity of Different Geometrical Isomers of $\alpha$-Carotene, $\beta$-Carotene, Lycopene, and Zeaxanthin. J. Agric. Food Chem. 2002, 50, 221-226. [CrossRef]

42. Awika, J.M.; Rooney, L.W.; Wu, X.; Prior, R.L.; Cisneros-Zevallos, L. Screening Methods to Measure Antioxidant Activity of Sorghum (Sorghum bicolor) and Sorghum Products. J. Agric. Food Chem. 2003, 51, 6657-6662. [CrossRef]

43. Arnao, M.B.; Cano, A.; Acosta, M. The hydrophilic and lipophilic contribution to total antioxidant activity. Food Chem. 2001, 73, 239-244. [CrossRef]

44. Blois, M.S. Antioxidant Determinations by the Use of a Stable Free Radical. Nature 1958, 181, 1199-1200. [CrossRef]

45. Brand-Williams, W.; Cuvelier, M.E.; Berset, C. Use of a free radical method to evaluate antioxidant activity. LWT Food Sci. Technol. 1995, 28, 25-30. [CrossRef]

46. Plank, D.W.; Szpylka, J.; Sapirstein, H.; Woollard, D.; Zapf, C.M.; Lee, V.; Chen, C.-Y.O.; Liu, R.H.; Tsao, R.; Düsterloh, A.; et al. Determination of Antioxidant Activity in Foods and Beverages by Reaction with 2,2'-Diphenyl-1-Picrylhydrazyl (DPPH): Collaborative Study First Action 2012.04. J. AOAC Int. 2012, 95, 1562-1569. [CrossRef]

47. Re, R.; Pellegrini, N.; Proteggente, A.; Pannala, A.; Yang, M.; Rice-Evans, C. Antioxidant activity applying an improved ABTS radical cation decoloration assay. Free Rad. Biol. Med. 1999, 26, 1231-1237. [CrossRef]

48. Roginsky, V.; Lissi, E. Review of methods to determine chain-breaking antioxidant activity in food. Food Chem. 2005, 92, 235-254. [CrossRef]

49. Ghiselli, A.; Serafini, M.; Maiani, G.; Azzini, E.; Ferro-Luzzi, A. A fluorescence-based method for measuring total plasma antioxidant capability. Free Radic. Biol. Med. 1995, 18, 29-36. [CrossRef]

50. Miller, N.J.; Rice-Evans, C.; Davies, M.J.; Gopinathan, V.; Milner, A. A Novel Method for Measuring Antioxidant Capacity and its Application to Monitoring the Antioxidant Status in Premature Neonates. Clin. Sci. 1993, 84, 407-412. [CrossRef]

51. Adom, K.K.; Liu, R.H. Rapid Peroxyl Radical Scavenging Capacity (PSC) Assay for Assessing both Hydrophilic and Lipophilic Antioxidants. J. Agric. Food Chem. 2005, 53, 6572-6580. [CrossRef]

52. Huang, D.; Ou, B.; Prior, R.L. The Chemistry behind Antioxidant Capacity Assays. J. Agric. Food Chem. 2005, 53, 1841-1856. [CrossRef] 
53. Wolfe, K.L.; Liu, R.H. Cellular Antioxidant Activity (CAA) Assay for Assessing Antioxidants, Foods, and Dietary Supplements. J. Agric. Food Chem. 2007, 55, 8896-8907. [CrossRef]

54. Yang, C.; Shahidi, F.; Tsao, R. Biomarkers of oxidative stress and cellular-based assays of indirect antioxidant measurement. In Measurement of Antioxidant Activity \& Capacity: Recent Trends and Applications; Apak, R., Capanoglu, E., Shahidi, F., Eds.; John Wiley \& Sons Ltd.: Hoboken, NJ, USA, 2018; pp. 165-186.

55. FDA. Nutrient Content Claims for "Good Source", "High", "More", and "High Potency". Available online: https://www.ecfr.gov/cgi-bin/text-idx?SID=f157cbe6acc56dd4486f7ff998e27aa8\&mc=true\& node $=$ se21.2.101_154\&rgn=div8. (accessed on 20 May 2020).

56. Turck, D.; Bresson, J.L.; Burlingame, B.; Dean, T.; Fairweather-Tait, S.; Heinonen, M.; Hirsch-Ernst, K.; Mangelsdorf, I.; Mcardle, H.; Naska, A.; et al. Guidance for the scientific requirements for health claims related to antioxidants, oxidative damage and cardiovascular health. EFSA J. 2018, 16, e05136. [CrossRef]

57. Giovannucci, E.; Ascherio, A.; Rimm, E.B.; Stampfer, M.J.; Colditz, G.A.; Willett, W.C. Intake of carotenoids and retinol in relation to risk of prostate cancer. J. Natl. Cancer Inst. 1995, 87, 1767-1776. [CrossRef] [PubMed]

58. Cooper, D.A. Carotenoids in health and disease: Recent scientific evaluations, research recommendations and the consumer. J. Nutr. 2004, 134, 221S-224S. [CrossRef] [PubMed]

59. Tapiero, H.; Townsend, D.M.; Tew, K.D. The role of carotenoids in the prevention of human pathologies. Biomed. Pharmacother. 2004, 58, 100-110. [CrossRef] [PubMed]

60. Hu, F.; Wang, Y.B.; Zhang, W.; Liang, J.; Lin, C.; Li, D.; Wang, F.; Pang, D.; Zhao, Y. Carotenoids and breast cancer risk: A meta-analysis and meta-regression. Breast Canc. Res. Treat. 2012, 131, 239-253. [CrossRef] [PubMed]

61. Wang, Y.; Chung, S.J.; McCullough, M.L.; Song, W.O.; Fernandez, M.L.; Koo, S.I.; Chun, O.K. Dietary carotenoids are associated with cardiovascular disease risk biomarkers mediated by serum carotenoid concentrations. J. Nutr. 2014, 144, 1067-1074. [CrossRef]

62. Arathi, B.P.; Sowmya, P.R.R.; Vijay, K.; Baskaran, V.; Lakshminarayana, R. Metabolomics of carotenoids: The challenges and prospects-A review. Trends Food Sci. Technol. 2015, 45, 105-117. [CrossRef]

63. World Cancer Research Fund, Continuous Update Project. Cancer Prevention Recommendations. Available online: https://www.wcrf.org/int/continuous-update-project (accessed on 20 March 2020).

64. Linnewiel, K.; Ernst, H.; Caris-Veyrat, C.; Ben-Dor, A.; Kampf, A.; Salman, H.; Danilenko, M.; Levy, J.; Sharoni, Y. Structure activity relationship of carotenoid derivatives in activation of the electrophile/antioxidant response element transcription system. Free Radic. Biol. Med. 2009, 47, 659-667. [CrossRef]

65. Ford, N.A.; Elsen, A.C.; Zuniga, K.; Lindshield, B.L.; Erdman, J.W., Jr. Lycopene and apo-120-lycopenal reduce cell proliferation and alter cell cycle progression in human prostate cancer cell. Nutr. Cancer 2011, 63, 256-263. [CrossRef]

66. Mein, J.R.; Dolnikowski, G.G.; Ernst, H.; Russell, R.M.; Wang, X.D. Enzymatic formation of apo-carotenoids from the xanthophyll carotenoids lutein, zeaxanthin, and $\beta$-cryptoxanthin by ferret carotene-9',10'-monooxygenase. Arch. Biochem. Biophys. 2011, 506, 109-121. [CrossRef]

67. Bohn, T.; McDougall, G.J.; Alegría, A.; Alminger, M.; Arrigoni, E.; Aura, A.-M.; Brito, C.; Cilla, A.; El, S.N.; Karakaya, S.; et al. Mind the gap-Deficits in our knowledge of aspects impacting the bioavailability of phytochemicals and their metabolites-A position paper focusing on carotenoids and polyphenols. Mol. Nutr. Food Res. 2015, 59, 1307-1323. [CrossRef]

68. Desmarcherlier, C.; Borel, P. Overview of carotenoid bioavailability determinants: From dietary factors to host genetic variations. Trends Food Sci. Nutr. 2017, 69, 270-280. [CrossRef]

69. Winklhofer-Roob, B.M.; Rock, E.; Ribalta, J.; Shmerling, D.H.; Roob, J.M. Effects of vitamin E and carotenoid status on oxidative stress in health and disease. Evidence obtained from human intervention studies. Mol. Aspects Med. 2003, 24, 391-402. [CrossRef]

70. Sommer, A.; Vyas, K.S. A global clinical view on vitamin A and carotenoids. Am. J. Clin. Nutr. 2012, 96, 1204S-1206S. [CrossRef] [PubMed]

71. Ruiz-Sola, M.A.; Rodríguez-Concepción, M. Carotenoid biosynthesis in Arabidopsis: A colorful pathway. Arab. Book 2012, 10, e0158. [CrossRef] [PubMed]

72. Liaaen-Jensen, S. Basic Carotenoid Chemistry. In Carotenoids in Health and Disease, 1st ed.; Krinsky, N.I., Mayne, S.T., Sies, H., Eds.; Marcel Dekker: New York, NY, USA, 2004; pp. 1-30. 
73. Khachik, F.; Beecher, G.R.; Goli, M.B. Separation, identification, and quantification of carotenoids in fruits, vegetables and human plasma by high performance liquid chromatography. Pure Appl. Chem. 1991, 63, 71-80. [CrossRef]

74. Viera, I.; Pérez-Gálvez, A.; Roca, M. Bioaccessibility of marine carotenoids. Mar. Drugs 2018, 16, 397. [CrossRef]

75. Maiani, G.; Caston, M.J.; Catasta, G.; Toti, E.; Cambrodon, I.G.; Bysted, A.; Granado-Lorencio, F.; Olmedilla-Alonso, B.; Knuthsen, P.; Valoti, M.; et al. Carotenoids: Actual knowledge on food sources, intakes, stability and bioavailability and their protective role in humans. Mol. Nutr. Food Res. 2009, 53, S194-S218. [CrossRef]

76. Landrum, J.; Bone, R. Lutein, zeaxanthin, and the macular pigment. Arch. Biochem. Biophys. 2001, 385, $28-40$. [CrossRef]

77. Clinton, S.K.; Emenhiser, C.; Schwartz, S.J.; Bostwick, D.G.; Williams, A.W.; Moore, B.J.; Erdman, J.W., Jr. Cis-trans lycopene isomers, carotenoids, and retinol in the human prostate. Cancer Epidemiol. Biomark. Prev. 1996, 5, 823-833.

78. Ríos, J.J.; Xavier, A.A.O.; Díaz-Salido, E.; Arenilla-Vélez, I.; Jarén-Galán, M.; Garrido-Fernández, J.; Aguayo-Maldonado, J.; Pérez-Gálvez, A. Xanthophyll esters are found in human colostrum. Mol. Nutr. Food Res. 2017, 61, 1700296. [CrossRef]

79. Olson, J.A. Benefits and liabilities of vitamin A and carotenoids. Rev. J. Nutr. 1996, 126, 1208S-1212S. [CrossRef] [PubMed]

80. Bendich, A.; Olson, J.A. Biological actions of carotenoids. FASEB J. 1989, 3, 1927-1932. [CrossRef] [PubMed]

81. Weber, D.; Grune, T. The contribution of $\beta$-carotene to vitamin A supply of humans. Mol. Nutr. Food Res. 2012, 56, 251-258. [CrossRef]

82. Burton, G.W.; Ingold, K.U. $\beta$-Carotene. An unusual type of lipid antioxidant. Science 1984, 224, 569-573. [CrossRef] [PubMed]

83. Foote, C.S.; Denny, R.W. Chemistry of singlet oxygen. VIII. Quenching by $\beta$-carotene. J. Am. Chem. Soc. 1968, 90, 6233-6235. [CrossRef]

84. Liebler, D.C. Antioxidant reactions of carotenoids. Ann. N. Y. Acad. Sci. 1993, 691, 20-31. [CrossRef]

85. Sies, H.; Stahl, W.; Sevanian, A. Nutritional, dietary and postprandial oxidative stress. J. Nutr. 2005, 135, 969-972. [CrossRef]

86. Stahl, W.; Sies, H. Bioactivity and protective effects of natural carotenoids. Biochim. Biophys. Acta 2005, 1740, 101-107. [CrossRef]

87. Stahl, W.; Sies, H. Carotenoids and flavonoids contribute to nutritional protection against skin damage from sunlight. Mol. Biotechnol. 2007, 37, 26-30. [CrossRef]

88. Jomova, K.; Kysel, O.; Madden, J.C.; Morris, H.; Enoch, S.J.; Budzak, S.; Young, A.J.; Cronin, M.T.D.; Mazur, M.; Valko, M. Electron transfer from all-trans $\beta$-carotene to the t-butyl peroxyl radical at low oxygen pressure (an EPR spectroscopy and computational study). Chem. Phys. Lett. 2009, 478, 266-270. [CrossRef]

89. Mortensen, A.; Skibsted, L.H. Kinetics of photobleaching of beta-carotene in chloroform and formation of transient carotenoid species absorbing in the near infrared. Free Rad. Res. 1996, 25, 355-368. [CrossRef] [PubMed]

90. Burke, M.; Edge, R.; Land, E.J.; McGarvey, D.J.; Truscott, T.G. One-electron reduction potentials of dietary carotenoid radical cations in aqueous micellar environments. FEBS Lett. 2001, 500, 132-136. [CrossRef]

91. Edge, R.; Land, E.J.; McGarvey, D.; Mulroy, L.; Truscott, G. Relative one-electron reduction potentials of carotenoid radical cations and the interactions of carotenoids with the vitamin E radical cation. J. Am. Chem. Soc. 1998, 120, 4087-4090. [CrossRef]

92. Mortensen, A.; Skibsted, L.H.; Willnow, A.; Everett, S.A. Re-appraisal of the tocopheroxyl radical reaction with beta-carotene: Evidence for oxidation of vitamin $\mathrm{E}$ by the beta-carotene radical cation. Free Radic. Res. 1998, 28, 69-80. [CrossRef]

93. Britton, G. Structure and properties of carotenoids in relation to function. FASEB J. 1995, 9, 1551-1558. [CrossRef]

94. Edge, R.; McGarvey, D.J.; Truscott, T.G. The carotenoids as antioxidants-A review. J. Photochem. Photobiol. $B$ 1997, 41, 189-200. [CrossRef]

95. Woodall, A.A.; Lee, S.W.; Weesie, R.j.; Jackson, M.J.; Britton, G. Oxidation of carotenoids by free radicals: Relationship between structure and reactivity. Biochim. Biophys. Acta 1997, 1336, 33-42. [CrossRef] 
96. Pérez-Gálvez, A.; Mínguez-Mosquera, M.I. Degradation of non-esterified and esterified xanthophylls by free radicals. Biochim. Biophys. Acta 2002, 1569, 31-34. [CrossRef]

97. Terao, J. Antioxidant activity of beta-carotene-related carotenoids in solution. Lipids 1989, 24, 659-661. [CrossRef]

98. Bartosz, G.; Janaszewska, A.; Ertel, D. Spectrophotomeric determination of peroxyl-radical trapping capacity. Curr. Top. Biphys. 1998, 22, 11-13.

99. Jomova, K.; Valko, M. Health protective effects of carotenoids and their interactions with other biological antioxidants. Eur. J. Med. Chem. 2013, 70, 102-110. [CrossRef]

100. Krinsky, N.I. Carotenoids as antioxidants. Nutrition 2001, 17, 815-817. [CrossRef]

101. Niki, E. Free radical initiators as source of water- or lipid-soluble peroxyl radicals. Methods Enzymol. 1990, 186, 100-108. [PubMed]

102. Bangham, A.D. The first description of liposomes. Curr. Content 1989, 13, 14.

103. Tsuchihashi, H.; Kigoshi, M.; Iwatsuki, M.; Niki, E. Action of $\beta$-carotene as an antioxidant against lipid peroxidation. Arch. Biochem. Biophys. 1995, 323, 137-147. [CrossRef] [PubMed]

104. Liebler, D.C.; Stratton, S.P.; Kaysen, K.L. Antioxidant actions of beta-carotene in liposomal and microsomal membranes: Role of carotenoid-membrane incorporation and alpha-tocopherol. Arch. Biochem. Biophys. 1997, 338, 244-250. [CrossRef] [PubMed]

105. Woodall, A.A.; Britton, G.; Jackson, M.J. Carotenoids and protection of phospholipids in solution or in liposomes against oxidation by peroxyl-radicals: Relationship between carotenoid structure and protective ability. Biochim. Biophys. Acta 1997, 1336, 575-586. [CrossRef]

106. Sujak, A.; Gabrielska, J.; Grudziński, W.; Borc, R.; Mazurek, P.; Gruszecki, W.I. Lutein and zeaxanthin as protectors of lipid membranes against oxidative damage: The structural aspects. Arch. Biochem. Biophys. 1999, 371, 301-307. [CrossRef]

107. Barros, M.P.; Pinto, E.; Colepicolo, P.; Pedersén, M. Astaxanthin and peridinin inhibit oxidative damage in $\mathrm{Fe}(2+)$-loaded liposomes: Scavenging oxyradicals or changing membrane permeability? Biochem. Biophys. Res. Commu. 2001, 288, 225-232. [CrossRef]

108. Wrona, M.; Korytowski, W.; Różanowska, M.; Sarna, T.; Truscott, T.G. Cooperation of antioxidants in protection against photosensitized oxidation. Free Rad. Biol. Med. 2003, 35, 1319-1329. [CrossRef]

109. Schroeder, M.T.; Becker, E.M.; Skibsted, L.H. Molecular mechanism of antioxidant synergism of tocotrienols and carotenoids in palm oil. J. Agric. Food Chem. 2006, 54, 3445-3453. [CrossRef] [PubMed]

110. Becker, E.M.; Ntouma, G.; Skibsted, L.H. Synergism and antagonism between quercetin and other chain-breaking antioxidants in lipid systems of increasing structural organization. Food Chem. 2007, 103, 1288-1296. [CrossRef]

111. McNulty, H.; Jacob, R.F.; Mason, R.P. Biologic activity of carotenoids related to distinct membrane physicochemical interactions. Am. J. Cardiol. 2008, 101, 20D-29D. [CrossRef]

112. Esterbauer, H.; Striegl, G.; Puhl, H.; Rotheneder, M. Continuous monitoring of in vitro oxidation of human low density lipoprotein. Free Radic. Res. Commun. 1989, 6, 67-75. [CrossRef] [PubMed]

113. Princen, H.M.; van Poppel, G.; Vogelezang, C.; Buytenhek, R.; Kok, F.J. Supplementation with vitamin E but not $\beta$-carotene in vivo protects low density lipoprotein from lipid peroxidation in vitro. Effect of cigarette smoking. Arterioscler. Thromb. Vasc. Biol. 1992, 12, 554-562. [CrossRef]

114. Hininger, I.; Chopra, M.; Thurnham, D.I.; Laporte, F.; Richard, M.-J.; Favier, A.; Roussel, A.-M. Effect of increased fruit and vegetable intake on the susceptibility of lipoprotein oxidation in smokers. Eur. J. Clin. Nutr. 1997, 51, 601-606. [CrossRef] [PubMed]

115. Kiokias, S.; Gordon, M.H. Dietary supplementation with a natural carotenoid mixture decreases oxidative stress. Eur. J. Clin. Nutr. 2003, 57, 1135-1140. [CrossRef]

116. Upritchard, J.E.; Schuurman, C.R.W.C.; Wiersma, A.; Tijburg, L.B.M.; Coolen, S.A.J.; Rijken, P.J.; Wiseman, S.A. Spread supplemented with moderate doses of vitamin $\mathrm{E}$ and carotenoids reduces lipid peroxidation in healthy, nonsmoking adults. Am. J. Clin. Nutr. 2003, 78, 985-992. [CrossRef]

117. Wang, Z.; Ciabattoni, G.; Créminon, C.; Lawson, J.; Fitzgerald, G.A.; Patrono, C.; Maclouf, J. Immunological characterization of urinary 8-epi-prostaglandin $\mathrm{F}_{2}$ excretion in man. J. Pharmacol. Exp. Ther. 1995, 275, 94-100.

118. Visioli, F.; Riso, P.; Grande, S.; Galli, C.; Porrini, M. Protective activity of tomato products on in vivo markers of lipid oxidation. Eur. J. Nutr. 2003, 42, 201-206. [CrossRef] 
119. Milde, J.; Elstner, E.F.; Grassmann, J. Synergistic effects of phenolics and carotenoids on human low-density lipoprotein oxidation. Mol. Nutr. Food Res. 2007, 51, 956-961. [CrossRef]

120. Neyestani, T.R.; Shariatzadeh, N.; Gharavi, A.; Kalyi, A.; Khalaji, N. Physiological dose of lycopene suppressed oxidative stress and enhanced serum levels of immunoglobulin $\mathrm{M}$ in patients with Type 2 diabetes mellitus: A possible role in the prevention of long-term complications. J. Endocrinol. Investig. 2007, 30, 833-838. [CrossRef] [PubMed]

121. Devaraj, S.; Mathur, S.; Basu, A.; Aung, H.H.; Vasu, V.T.; Meyers, S.; Jialal, I. A dose-response study on the effects of purified lycopene supplementation on biomarkers of oxidative stress. J. Am. Coll. Nutr. 2008, 27, 267-273. [CrossRef] [PubMed]

122. Kim, J.Y.; Paik, J.K.; Kim, O.Y.; Park, H.W.; Lee, J.H.; Jang, Y.; Lee, J.H. Effects of lycopene supplementation on oxidative stress and markers of endothelial function in healthy men. Atherosclerosis 2011, 215, 189-195. [CrossRef] [PubMed]

123. Burri, B.J. Carotenoids and gene expression. Nutrition 2000, 16, 577-578. [CrossRef]

124. Palozza, P.; Serini, S.; Torsello, A.; Di Nicuolo, F.; Piccioni, E.; Ubaldi, V.; Pioli, C.; Wolf, F.I.; Calviello, G. $\beta$-carotene regulates NF-kB DNA-binding activity by a redox mechanism in human leukemia and colon adenocarcinoma cells. J. Nutr. 2003, 133, 381-388. [CrossRef]

125. Liu, C.L.; Chiu, Y.T.; Hu, M.L. Fucoxanthin enhances HO-1 and NQO1 expression in murine hepatic BNL CL.2 cells through activation of the Nrf2/ARE system partially by its pro-oxidant activity. J. Agric. Food Chem. 2011, 59, 11344-11351. [CrossRef]

126. Palozza, P.; Catalano, A.; Simone, R.; Cittadini, A. Lycopene as a guardian of redox signalling. Acta Biochim. Pol. 2012, 59, 21-25. [CrossRef]

127. Stahl, W.; von Laar, J.; Martin, H.D.; Emmerich, T.; Sies, H. Stimulation of gap junctional communication: Comparison of acyclo-retinoic acid and lycopene. Arch. Biochem. Biophys. 2000, 373, 271-274. [CrossRef]

128. Aust, O.; Ale-Agha, N.; Zhang, L.; Wollersen, H.; Sies, H.; Stahl, W. Lycopene oxidation product enhances gap junctional communication. Food Chem. Toxicol. 2003, 41, 1399-1407. [CrossRef]

129. Echtay, K.S.; Esteves, T.C.; Pakay, J.L.; Jekabsons, M.B.; Lambert, A.J.; Portero-Otín, M.; Pamplona, R.; Vidal-Puig, A.J.; Wang, S.; Roebuck, S.J.; et al. A signalling role for 4-hydroxy-2-nonenal in regulation of mitochondrial uncoupling. EMBO J. 2003, 22, 4103-4110. [CrossRef] [PubMed]

130. Siems, W.; Capuozzo, E.; Crifò, C.; Sommerburg, O.; Langhans, C.-D.; Schlipalius, L.; Wiswedel, I.; Kraemer, K.; Salerno, C. Carotenoid cleavage products modify respiratory burst and induce apoptosis of human neutrophils. Biochim. Biophys. Acta 2003, 1639, 27-33. [CrossRef]

131. Amengual, J.; Lobo, G.P.; Golczak, M.; Li, H.N.; Klimova, T.; Hoppel, C.L.; Wyss, A.; Palczewski, K.; von Lintig, J. A mitochondrial enzyme degrades carotenoids and protects against oxidative stress. FASEB J. 2011, 25, 948-959. [CrossRef] [PubMed]

132. Martin, K.R.; Failla, M.L.; Smith, J.C. Beta-carotene and lutein protect HepG2 human liver cells against oxidant-induced damage. J. Nutr. 1996, 126, 2098-2106. [CrossRef] [PubMed]

133. Palozza, P.; Luberto, C.; Calviello, G.; Ricci, P.; Bartoli, G.M. Antioxidant and prooxidant role of beta-carotene in murine normal and tumor thymocytes: Effects of oxygen partial pressure. Free Radic. Biol. Med. 1997, 22, 1065-1073. [CrossRef]

134. Bohn, T. Carotenoids and Markers of Oxidative Stress in Human Observational Studies and Intervention Trials: Implications for Chronic Diseases. Antioxidants 2019, 8, 179. [CrossRef]

135. Lowe, G.; Booth, L.A.; Young, A.J.; Bilton, Y.R. Lycopene and b-carotene protect against oxidative damage in HT29 cells at low concentrations but rapidly lose this capacity at higher doses. Free Radic. Res. 1999, 30, 141-151. [CrossRef]

136. Matos, H.R.; Di Mascio, P.; Medeiros, M.H.G. Protective effect of lycopene on lipid peroxidation and oxidative DNA damage in cell culture. Arch. Biochem. Biophys. 2000, 383, 56-59. [CrossRef]

137. Yeh, S.-L.; Hu, M.-L. Antioxidant and pro-oxidant effects of lycopene in comparison with b-carotene on oxidant-induced damage in Hs68 cells. J. Nutr. Biochem. 2000, 11, 548-554. [CrossRef]

138. Offord, E.A.; Gautier, J.C.; Avanti, O.; Scaletta, C.; Runge, F.; Krämer, K.; Applegate, L.A. Photoprotective potential of lycopene, beta-carotene, vitamin E, vitamin C and carnosic acid in UVA-irradiated human skin fibroblasts. Free Radic. Biol. Med. 2002, 32, 1293-1303. [CrossRef] 
139. Ochiai, T.; Ohno, S.; Soeda, S.; Tanaka, H.; Shoyama, Y.; Shimeno, H. Crocin prevents the death of rat pheochromyctoma (PC-12) cells by its antioxidant effects stronger than those of alpha-tocopherol. Neurosci. Lett. 2004, 362, 61-64. [CrossRef]

140. Chucair, A.J.; Rotstein, N.P.; Sangiovanni, J.P.; During, A.; Chew, E.Y.; Politi, L.E. Lutein and zeaxanthin protect photoreceptors from apoptosis induced by oxidative stress: Relation with docosahexaenoic acid. Investig. Ophthalmol. Vis. Sci. 2007, 48, 5168-5177. [CrossRef]

141. Ajila, C.M.; Prasada Rao, U.J. Protection against hydrogen peroxide induced oxidative damage in rat erythrocytes by Mangifera indica L. peel extract. Food Chem. Toxicol. 2008, 46, 303-309. [CrossRef]

142. Camera, E.; Mastofrancesco, A.; Fabbri, C.; Daubrawa, F.; Picardo, M.; Sies, H.; Stahl, W. Astaxanthin, canthaxanthin and beta-carotene differently affect UVA-induced oxidative damage and expression of oxidative stress-responsive enzymes. Exp. Dermatol. 2009, 18, 222-231. [CrossRef]

143. Wolf, A.M.; Asoh, S.; Hirnuma, H.; Ohsawa, I.; Iio, K.; Satou, A.; Ishikura, M.; Ohta, S. Astaxanthin protects mitochondrial redox state and functional integrity against oxidative stress. J. Nutr. Biochem. 2010, 21, 381-389. [CrossRef]

144. Yamauchi, M.; Tsuruma, K.; Imai, S.; Nakanishi, T.; Umigai, N.; Shimazawa, M.; Hara, H. Crocetin prevents retinal degeneration induced by oxidative and endoplasmic reticulum stresses via inhibition of caspase activity. Eur. J. Pharmacol. 2011, 650, 110-119. [CrossRef]

145. Fernández-García, E.; Carvajal-Lérida, I.; Pérez-Gálvez, A. Carotenoids exclusively synthesized in red pepper (capsanthin and capsorubin) protect human dermal fibroblasts against UVB induced DNA damage. Photochem. Photobiol. Sci. 2016, 15, 1204-1211. [CrossRef]

146. Usuki, R.; Endo, Y.; Kaneda, T. Prooxidant activities of chlorophylls and pheophytins on the photooxidation of edible oils. Agric. Biol. Chem. 1984, 48, 991-994. [CrossRef]

147. Rigane, G.; Bouaziz, M.; Sayadi, S.; Salem, R.B. Effect of storage on refined olive oil composition: Stabilization by addition of chlorophyll pigments and squalene. J. Oleo Sci. 2013, 62, 981-987. [CrossRef]

148. Ferruzzi, M.G.; Bohm, V.; Courtney, P.D.; Schwartz, S.J. Antioxidant and Antimutagenic Activity of Dietary Chlorophyll Derivatives Determined by Radical Scavenging and Bacterial Reverse Mutagenesis Assays. J. Food Sci. 2002, 67, 2589-2595. [CrossRef]

149. Lanfer-Marquez, U.M.; Barros, R.M.C.; Sinnecker, P. Antioxidant activity of chlorophylls and their derivatives. Food Res. Int. 2005, 38, 885-891. [CrossRef]

150. Nagini, S.; Palitti, F.; Natarajan, A.T. Chemopreventive potential of chlorophyllin: A review of the mechanisms of action and molecular targets. Nutr. Cancer 2015, 67, 203-211. [CrossRef]

151. Tumolo, T.; Lanfer-Marquez, U.M. Copper chlorophyllin: A food colorant with bioactive properties? Food Res. Int. 2012, 46, 451-459. [CrossRef]

152. Ferruzzi, M.G.; Blakeslee, J. Digestion, absorption, and cancer preventative activity of dietary chlorophyll derivatives. Nutr. Res. 2007, 27, 1-12. [CrossRef]

153. Ferruzzi, M.G.; Failla, M.L.; Schwartz, S.J. Assessment of degradation and intestinal cell uptake of carotenoids and chlorophyll derivatives from spinach puree using an in vitro digestion and Caco-2 human cell model. J. Agric. Food Chem. 2001, 49, 2082-2089. [CrossRef]

154. Gallardo-Guerrero, L.; Gandul-Rojas, B.; Mínguez-Mosquera, M.I. Digestive stability, micellarization, and uptake by Caco-2 human intestinal cell of chlorophyll derivatives from different preparations of pea (Pisum sativum L.). J. Agric. Food Chem. 2008, 56, 8379-8386. [CrossRef]

155. Gandul-Rojas, B.; Gallardo-Guerrero, L.; Mínguez-Mosquera, M.I. Influence of the chlorophyll pigment structure on its transfer from an oily food matrix to intestinal epithelium cells. J. Agric. Food Chem. 2009, 57, 5306-5314. [CrossRef]

156. Chen, K.; Roca, M. In vitro digestion of chlorophyll pigments from edible seaweeds. J. Funct. Foods 2018, 40, 400-407. [CrossRef]

157. Chen, K.; Roca, M. Cooking Effects on Bioaccessibility of Chlorophyll Pigments of the Main Edible Seaweeds. Food Chem. 2019, 295, 101-109. [CrossRef]

158. Chen, K.; Roca, M. In vitro bioavailability of chlorophyll pigments from edible seaweeds. J. Func. Foods 2018, 41, 25-33. [CrossRef]

159. Viera, I.; Chen, K.; Ríos, J.J.; Benito, I.; Pérez-Gálvez, A.; Roca, M. First-pass metabolism of chlorophylls in mice. Mol. Nutr. Food Res. 2018, 62, 1800562. [CrossRef] [PubMed] 
160. Egner, P.A.; Stansbury, K.H.; Snyder, E.P.; Rogers, M.E.; Hintz, P.A.; Kensler, T.W. Identification and characterization of chlorin e4 ethyl ester in sera of individuals participating in the chlorophyllin chemoprevention trial. Chem. Res. Toxicol. 2000, 13, 900-906. [CrossRef] [PubMed]

161. Fernandes, A.S.; Nogara, G.P.; Menezes, C.R.; Cichoski, A.J.; Mercadante, A.Z.; Jacob-Lopes, E.; Zepka, L.Q. Identification of chlorophyll molecules with peroxyl radical scavenger capacity in microalgae Phormidium autumnale using ultrasound-assisted extraction. Food Res. Int. 2017, 99, 1036-1041. [CrossRef]

162. Hsu, C.Y.; Yang, C.M.; Chen, C.M.; Chao, P.Y.; Hu, S.P. Effects of chlorophyll-related compounds on hydrogen peroxide induced DNA damage within human lymphocytes. J. Agric. Food Chem. 2005, 6, 2746-2750. [CrossRef]

163. Hoshina, C.; Tomita, K.; Shioi, Y. Antioxidant activity of chlorophylls: Its structure-activity relationship. In Photosynthesis: Mechanisms Effects; Garab, G., Ed.; Springer: Dordrecht, The Netherlands, 1998; Volume 4, pp. 3281-3284.

164. Suzuki, N.; Hatate, H.; Kanamori, N.; Nomoto, T.; Namiki, M.; Yoda, B. Antioxidative Activity of Chlorophyll Derivatives, Oxygen Stress Relievers, to Superoxide Measured by Using Cypridina Luciferin Analogues. Fish. Sci. 1995, 61, 65-67. [CrossRef]

165. Kang, Y.-R.; Park, J.; Jung, S.K.; Chang, Y.H. Synthesis, characterization, and functional properties of chlorophylls, pheophytins, and Zn-pheophytins. Food Chem. 2018, 245, 943-950. [CrossRef]

166. Endo, Y.; Usuki, R.; Kaneda, T. Antioxidant effects of chlorophyll and pheophytin on the autoxidation of oils in the dark. II. The mechanism of antioxidative action of chlorophyll. J. Am. Oil Chem. Soc. 1985, 62, 1387-1390. [CrossRef]

167. Viera, I.; Pérez-Gálvez, A.; Roca, M. Green Natural Colorants. Molecules 2019, 24, 154. [CrossRef]

168. Sato, M.; Imai, K.; Kimura, R.; Murata, T. Effect of sodium copper chlorophyllin on lipid peroxidation. VI. Effect of its administration on mitochondrial and microsomal lipid peroxidation in rat liver. Chem. Pharm. Bull. 1984, 32, 716-722. [CrossRef]

169. Gerić, M.; Gajski, G.; Mihaljević, B.; Miljanić, S.; Domijan, A.M.; Garaj-Vrhovac, V. Radioprotective properties of food colorant sodium copper chlorophyllin on human peripheral blood cells in vitro. Mutat. Res. 2019, 845, 403027. [CrossRef]

170. Zhan, R.; Wu, J.; Ouyang, J. In vitro Antioxidant Activities of Sodium Zinc and Sodium Iron Chlorophyllins from Pine Needles. Food Technol. Biotechnol. 2014, 52, 505-510. [CrossRef]

171. Hsu, C.-Y.; Chao, P.-Y.; Hu, S.-P.; Yang, C.-M. The Antioxidant and Free Radical Scavenging Activities of Chlorophylls and Pheophytins. Food Nutr. Sci. 2013, 4, 35234. [CrossRef]

172. Jeon, Y.-M.; Lee, H.-S.; Jeong, D.; Oh, H.-K.; Ra, K.-H.; Lee, M.-Y. Antimicrobial photodynamic therapy using chlorin e6 with halogen light for acne bacteria-induced inflammation. Life Sci. 2015, 124, 56-63. [CrossRef] [PubMed]

173. Serpeloni, J.M.; Grotto, D.; Aissa, A.F.; Mercadante, A.Z.; Bianchi, M.d.L.P.; Antunes, L.M.G. An evaluation, using the comet assay and the micronucleus test, of the antigenotoxic effects of chlorophyll $\mathrm{b}$ in mice. Mutat. Res. Genet. Toxicol. Environ. 2011, 725, 50-56. [CrossRef]

174. Le Tutour, B.; Benslimane, F.; Gouleau, M.; Gouygou, J.P.; Saadan, B.; Quemeneur, F. Antioxidant and pro-oxidant activities of the brown algae, Laminaria digitata, Himanthalia elongata, Fucus vesiculosus, Fucus serratus and Ascophyllum nodosum. J. Appl. Phycol. 1998, 10, 121-129. [CrossRef]

175. Osuna-Ruiz, I.; López-Saiz, C.-M.; Burgos-Hernández, A.; Velázquez, C.; Nieves-Soto, M.; Hurtado-Oliva, M.A. Antioxidant, antimutagenic and antiproliferative activities in selected seaweed species from Sinaloa, Mexico. Pharm. Biol. 2016, 54, 2196-2210. [CrossRef] [PubMed]

176. Cho, M.; Lee, H.-S.; Kang, I.-J.; Won, M.-H.; You, S. Antioxidant properties of extract and fractions from Enteromorpha prolifera, a type of green seaweed. Food Chem. 2011, 127, 999-1006. [CrossRef] [PubMed]

177. Batista, A.P.; Niccolai, A.; Bursic, I.; Sousa, I.; Raymundo, A.; Rodolfi, L.; Biondi, N.; Tredici, M.R. Microalgae as Functional Ingredients in Savory Food Products: Application to Wheat Crackers. Foods 2019, $23,611$. [CrossRef]

178. Zen, C.K.; Tiepo, C.B.V.; da Silva, R.V.; Reinehr, C.O.; Gutkoski, L.C.; Oro, T.; Colla, L.M. Development of functional pasta with microencapsulated Spirulina: Technological and sensorial effects. J. Sci. Food Agric. 2020, 30, 2018-2026. [CrossRef]

179. Sarker, U.; Oba, S. Nutrients, minerals, pigments, phytochemicals, and radical scavenging activity in Amaranthus blitum leafy vegetables. Sci. Rep. 2020, 10, 3868. [CrossRef] 
180. Durga devi, M.; Banu, N. Study of Antioxidant Activity of Chlorophyll from Some Medicinal Plants Paripex. Indian J. Res. 2015, 4, 6-8.

181. Alvarez-Parrilla, E.; de la Rosa, L.A.; Amarowicz, R.; Shahidi, F. Antioxidant Activity of Fresh and Processed Jalapeño and Serrano Peppers. J. Agric. Food Chem. 2011, 59, 163-173. [CrossRef]

182. Suparmi, S.; Fasitasari, M.; Martosupono, M.; Mangimbulude, J.C. Comparisons of Curative Effects of Chlorophyll from Sauropus androgynus (L) Merr Leaf Extract and Cu-Chlorophyllin on Sodium Nitrate-Induced Oxidative Stress in Rats. J. Toxicol. 2016, 2016, 8515089. [CrossRef] [PubMed]

183. Zhang, Z.H.; Peng, H.; Woo, M.W.; Zeng, X.A.; Brennan, M.; Brennan, C.S. Preparation and characterization of whey protein isolate-chlorophyll microcapsules by spray drying: Effect of WPI ratios on the physicochemical and antioxidant properties. J. Food Eng. 2020, 267, 109729. [CrossRef]

184. Kamat, J.P.; Boloor, K.K.; Devasagayam, T.P.A. Chlorophyllin as an effective antioxidant against membrane damage in vitro and ex vivo. BBA Mol. Cell Biol. Lip. 2000, 1487, 113-127. [CrossRef]

185. Kumar, S.S.; Shankar, B.; Sainis, K.B. Effect of chlorophyllin against oxidative stress in splenic lymphocytes in vitro and in vivo. BBA Gen. Subj. 2004, 1672, 100-111. [CrossRef]

186. Choi, K.; Ortega, M.T.; Jeffery, B.; Riviere, J.E.; Monteiro-Riviere, N.A. Oxidative stress response in canine in vitro liver, kidney and intestinal models with seven potential dietary ingredients. Toxicol. Lett. 2016, 22, 49-59. [CrossRef]

187. Vaňková, K.; Marková, I.; Jašprová, J.; Dvořák, A.; Subhanová, I.; Zelenka, J.; Novosádová, I.; Rasl, J.; Vomastek, T.; Sobotka, R.; et al. Chlorophyll-Mediated Changes in the Redox Status of Pancreatic Cancer Cells Are Associated with Its Anticancer Effects. Oxid. Med. Cell Longev. 2018, 2, 4069167. [CrossRef]

188. Sato, M.; Fujimoto, I.; Sakai, T.; Aimoto, T.; Kimura, R.; Murata, T. Effect of sodium copper chlorophyllin on lipid peroxidation. IX On the antioxidative components in commercial preparations of sodium copper chlorophyllin. Chem. Pharm. Bull. 1986, 34, 2428-2434. [CrossRef]

189. Patar, A.K.; Bhan, S.; Syiem, D.; Sharma, A. Ameliorative Effect of Chlorophyllin on Oxidative Stress in Experimental Model of Diabetes. Int. J. Phytomed. 2016, 8, 506-513. [CrossRef]

190. Wunderlich, A.L.M.; Azevedo, S.C.S.F.; Yamada, L.A.; Bataglini, C.; Previate, C.; Campanholi, K.S.S.; Pereira, P.C.S.; Caetano, W.; Kaplum, V.; Nakamura, C.V.; et al. Chlorophyll treatment combined with photostimulation increases glycolysis and decreases oxidative stress in the liver of type 1 diabetic rats. Braz. J. Med. Biol. Res. 2020, 53, e8389. [CrossRef]

191. Gomes, B.B.; Barros, S.B.M.; Andrade-Wartha, E.R.S.; Silva, A.M.O.; Silva, V.V.; Lanfer-Marquez, U.M. Bioavailability of dietary sodium copper chlorophyllin and its effect on antioxidant defence parameters of Wistar rats. J. Sci. Food Agric. 2009, 89, 2003-2010. [CrossRef]

192. Patar, A.K.; Sharma, A.; Syiem, D.; Bhan, S. Chlorophyllin supplementation modulates hyperglycemia-induced oxidative stress and apoptosis in liver of streptozotocin-administered mice: Chlorophyllin modulates hyperglycemia-induced oxidative stress and apoptosis. BioFactors 2018, 44, 418-430. [CrossRef] [PubMed]

193. O'Neill, P.; Fielden, E.M. Primary Free Radical Processes in DNA. In Advances in Radiation Biology; Lett, J.T., Sinclair, W.K., Eds.; Academic Press: New York, NY, USA, 1993; pp. 53-120.

194. Kumar, S.S.; Chaubey, R.C.; Devasagayam, T.P.; Priyadarsini, K.I.; Chauhan, P.S. Inhibition of radiation-induced DNA damage in plasmid pBR322 by chlorophyllin and possible mechanism(s) of action. Mutat. Res. 1999, 10, 71-79. [CrossRef]

195. Ibrahim, M.A.; Elbehairy, A.M.; Ghoneim, M.A.; Amer, H.A. Protective effect of curcumin and chlorophyllin against DNA mutation induced by cyclophosphamide or benzo[a]pyrene. Z. Naturforsch. 2007, 62, 215-222. [CrossRef]

196. Kavitha, K.; Thiyagarajan, P.; Rathna Nandhini, J.; Mishra, R.; Nagini, S. Chemopreventive effects of diverse dietary phytochemicals against DMBA-induced hamster buccal pouch carcinogenesis via the induction of Nrf2-mediated cytoprotective antioxidant, detoxification, and DNA repair enzymes. Biochimie 2013, 95, 1629-1639. [CrossRef]

197. Dalle-Donne, I.; Rossi, R.; Giustarini, D.; Milzani, A.; Colombo, R. Protein carbonyl groups as biomarkers of oxidative stress. Clinic. Chim. Acta 2003, 329, 23-38. [CrossRef]

198. Zhang, D.; Robinson, K.; Mihai, D.M.; Washington, I. Sequestration of ubiquitous dietary derived pigments enables mitochondrial light sensing. Sci. Rep. 2016, 6, 34320. [CrossRef] 
199. Zhang, M.; An, C.; Gao, Y.; Leak, R.K.; Chen, J.; Zhang, F. Emerging roles of Nrf2 and phase II antioxidant enzymes in neuroprotection. Prog. Neurobiol. 2013, 100, 30-47. [CrossRef] [PubMed]

200. Fahey, J.W.; Stephenson, K.K.; Dinkova-Kostova, A.T.; Egner, P.A.; Kensler, T.W.; Talalay, P. Chlorophyll, chlorophyllin and related tetrapyrroles are significant inducers of mammalian phase 2 cytoprotective genes. Carcinogenesis 2005, 26, 1247-1255. [CrossRef]

201. Suryavanshi, S.; Sharma, D.; Checker, R.; Thoh, M.; Gota, V.; Sandur, S.K.; Sainis, K.B. Amelioration of radiation-induced hematopoietic syndrome by an antioxidant chlorophyllin through increased stem cell activity and modulation of hematopoiesis. Free Radic. Biol. Med. 2015, 85, 56-70. [CrossRef]

202. Ozcan, M.; Esendagli, G.; Musdal, Y.; Canpinar, H.; Bacanlı, M.; Anlar, H.G.; Esendağl1-Yılmaz, G.; Beyramzadeh, M.; Aksoy, Y. Dual actions of the antioxidant chlorophyllin, a glutathione transferase P1-1 inhibitor, in tumorigenesis and tumor progression. J. Cell Biochem. 2019, 120, 7045-7055. [CrossRef]

203. McCarty, M.F. The chlorophyll metabolite phytanic acid is a natural rexinoid-Potential for treatment and prevention of diabetes. Med. Hypotheses 2001, 56, 217-219. [CrossRef]

204. Mukherjee, R.; Davies, P.J.A.; Crombie, D.L.; Bischoff, E.D.; Cesario, R.M.; Jow, L.; Hamann, L.G.; Boehm, M.F.; Mondon, C.E.; Nadzan, A.M.; et al. Sensitization of diabetic and obese mice to insulin by retinoid X receptor agonists. Nature 1997, 386, 407-410. [CrossRef]

205. Wang, E.; Wink, M. Chlorophyll enhances oxidative stress tolerance in Caenorhabditis elegans and extends its lifespan. Peer J. 2016, 4, e1879. [CrossRef]

206. Zhao, Y.; Yang, R.; Rui, Q.; Wang, D. Intestinal Insulin Signaling Encodes Two Different Molecular Mechanisms for the Shortened Longevity Induced by Graphene Oxide in Caenorhabditis elegans. Sci. Rep. 2016, 6, 24024. [CrossRef]

(C) 2020 by the authors. Licensee MDPI, Basel, Switzerland. This article is an open access article distributed under the terms and conditions of the Creative Commons Attribution (CC BY) license (http://creativecommons.org/licenses/by/4.0/). 